\title{
THE ROYAL LIBRARIES OF NINEVEH: NEW EVIDENCE FOR KING ASHURBANIPAL'S TABLET COLLECTING
}

\author{
$B y$ GRANT FRAME and A. R. GEORGE
}

The two tablets published here for the first time, BM 45642 and $\mathrm{BM} 28825,{ }^{1}$ are edited together for good reason, for the historical background of both texts is very probably the same episode in King Ashurbanipal's drive to acquire scribal learning. Where BM 28825 concerns the reception of the Assyrian king's demand for tablets among the citizens of Babylon, BM 45642 deals with the reaction of scholars of nearby Borsippa to a similar royal message. BM 45642 is the better preserved of the two tablets, and allows a fuller understanding of both texts' formal characteristics and of the contextual background. Consequently we present it first.

\section{Ashurbanipal and the scholars of Borsippa}

The text inscribed on BM $45642(81-7-6,35)$ is a letter, though not a typical one. It begins with an extremely deferential address to Ashurbanipal (11. 1-4). Following a series of standard royal epithets, the address pays homage to the Assyrian king as the divinely appointed suzerain of Assyria and Babylonia. It goes on to record Nabû's patronage of the king, and to acknowledge his skill in Nabû's special field of writing, an expertise already well known from Ashurbanipal's own inscriptions. These clauses are chosen with care, for the writer is evidently a scholar from Borsippa, Nabû's cult-centre. With them he invokes a certain feeling of mutual fellowship. The name of the sender is expected at the end of the address, but although the end of 1.4 is broken there does not seem to be a name there, and we have restored instead nilt [apra umma] "we send word as follows". In this the text departs from normal Neo-Babylonian usage, perhaps because it is not a regular letter but, as becomes clear, a formal and collective communication on behalf of all the scholars of Borsippa.

The blessings that open the scholars' message call for the local gods to show favour to the king, not just Marduk in Babylon, but also Nabû and Nanay of Borsippa (11. 5-7). The body of the letter is then introduced by a repetition of the word umma. It begins by identifying the writers as loyal subjects of the king who will execute his command and despatch to him the results (1.8). Ashurbanipal's command is then quoted: he has asked the scholars of Borsippa to copy out and send him all the texts of the scribal tradition held in the library of Nabû's temple (11. 9-10). This temple, called E-zida, is known to have been an important repository of scribal learning, especially from those first-millennium colophons that record the deposition there of literary tablets as votive offerings to Nabû (Hunger 1968: Nos. 135-6, 138-40a). The letter continues by anticipating the king's suspicions that the scholars of Borsippa will try to wriggle out of his commission by duplicity, as scribes of nearby Babylon are accused of doing, and protests that they will work day and night until the task is done and the texts copied on to writing-boards (ll. 10-12). In the disparaging remark about the scholars of Babylon, the letter reveals a rivalry between the scribal communities of the capital, Babylon, and Borsippa. It is not unexpected that an element of chauvinism should inform scribal life in Babylonia. A similar rivalry can be seen in a Sumerian practice letter of a much earlier time, in which scholars of Nippur cast doubts on the competence of their colleagues in the nearby capital, Isin (van Dijk 1989: 450).

There is one item that the scholars of Borsippa cannot help with, however. A Sumero-Akkadian glossary wanted by the king exists only at Babylon, in the temple of Marduk, and the king should

\footnotetext{
${ }^{1}$ The tablets are published by permission of the Trustees of the British Museum. BM 45642 was entrusted to George for publication by W. G. Lambert in 1985. BM 28825 was identified by Erle Leichty at about the same time and passed on to his pupil, Pamela Gerardi, who in 1999 gave her notes and preliminary hand copy to Frame. To these three colleagues we express our thanks; especial appreciation is

owed to Gerardi for her initial decipherment of BM 28825. We are also grateful to Simo Parpola, who on learning of our collaboration graciously dropped advanced plans to publish BM 28825. Part 1 of this article was contributed in draft by George, Part 2 by Frame; Part 3 is a joint effort. Both authors shared in the final draft of the whole. The cuneiform copies are by George. 
pursue the matter with the Babylonians (11. 12-14). This very glossary may be at issue in the text of the second tablet published here, where Ashurbanipal mentions such a composition in his message to the scholars of Babylon (BM 28825: 27). The text of BM 45642 now becomes fragmentary (11. 15-17); the passage ends with a reiteration that the scholars of Borsippa will indeed do the king's bidding. The letter then closes with routine prayers that the great powers in the universe grant the king health and happiness (11. 18-20).

The letter contains many flourishes of Standard Babylonian literary style. Word order is the most striking vehicle for literary effect, with use of non-final verbs very conspicuous:

kunnušu ana țup̌sarrūti kīma yāti (1. 4), lişbat abbūtka (7), lišamqit ayyābīka lihtalliq ... -ka (7), utarrūšsu našpartu (8), 'šllli'à našpartu (10), niggu ina lišăni dalihti (10-11), nušallam našpartu (11 and 17), nišattar

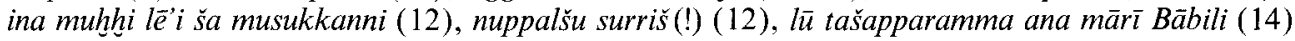

The introductory address includes other examples of elevated style: a chiastic construction: šarrūt māt Aššur iqīpūšsu ušatlimūšsu šarrūt māti kalāma (2), two examples of the locative: qātuššu (3), imnuššu (3), and an apocopated pronominal suffix on a false locative: libbuš for libbǐšu (1). The use of Standard Babylonian literary effects is unsurprising in a formal communication composed by a member, no doubt a senior one, of Borsippa's learned intellectual élite.

Elsewhere, however, the text exhibits clear examples of Neo-Babylonian orthography and dialect, especially in the body of the letter and its rubric:

kiš-šat (1. 1) for SB kiššati, i-qip-pu-uš-šú (2) for SB iqīpǚš, šu-tu-ra-' (9) for SB šutrā, šul-li-'-a (10) for SB šullimā, eninni (11), ni-na-ȟu ni-dal-li-pu (11) for SB ninâh nidallip, alla (13), yà̄nu (13), enni "now" (13), ki-ni (15) perhaps for SB kìn, gabbu (17? and 21), śá-tár an-na-a (21) for SB šatru annû, šu-ú-li (21) for SB $\breve{s u} l u$

As is the habit of late scribes, inflected endings on noun and verb are not written according to earlier rules. The subjunctive is marked variously:

-Ø: ’́-ma-'-ir-šu-ma (2), ú-šat-lim-šú (2), na-ši (3)

-Cu: i-qip-pu-uš-šú (2), iš-ruk-ku-šu-ma ku-un-nu-šú (4), ni-ig-gu (10), taš-pu-ru (13)

-Ci: it-muh-hi (3)

The present inscription is known from a tablet made long after the time of Ashurbanipal (see below). A rubric is appended, stating that the original - the scholars' letter to the king - was copied on to one or more stone tablets and circulated (1.21). This is an unusual destiny for a letter and emphasizes how important it was in the eyes of either its writers or the royal addressee. Presumably the drafts on stone were made after the original letter was sent to the king. The noun describing the recipients of the stone tablets is problematic, but may denote members of the scholarly community. The purpose of the transfer of the letter on to stone was no doubt to preserve on permanent monuments Ashurbanipal's choice of Borsippan scholars to execute his royal command, and thereby to enhance their scholarly prestige.

At all events, the text and its rubric became part of the scribal tradition, for the colophon of BM 45642 records that it was made by Nabû-mušetiq-uddi as the property of his father, Bēluballissu (11. 22-3). This is a scenario typical of Late Babylonian scribal apprenticeship, and marks the tablet out as a pedagogical assignment (George 2003: 37-8). Errors in the text confirm the impression that the tablet is not the work of a master:

$t u$ written for $l i$ (1.7), dittography of šam (7), tal-liq written for lihtalliq (7), erased a (9), nisattar inadvertently left out and interpolated later on left edge (12), suur-qi-ǐs probably written for sur-ri-ǐs (i2), ul.dù.a written for ud.ul.dù.a (12), gim šú written for gim labiri-š̉u (22)

The date of Nabû-mušêtiq-uddi's tablet is uncertain, but the cryptic spelling he used in his colophon for the verb ipašsit also occurs on a tablet written in $148 \mathrm{BC}$, during the reign of the Seleucid Alexander Balas (see below, the note on 1.23). Nabû-musētiq-uddi's family, the Mušēzibs, were scholars active at Babylon well into the ensuing Parthian period (e.g. George 2003: 740 MS b). While Late Babylonian palaeography remains undescribed, there is no clear picture of the evolution of Late Babylonian sign forms, nor of variation from place to place. For the moment all that can be done is to note the lack of the top horizontal wedge on signs such as $l u, k u$, gil, eme and $\breve{s a r}$ as suggestive of a date of writing somewhere in the twilight of cuneiform.

The short prayer to Marduk and Zarpanitum inscribed on the top edge of BM 45642 is typical of Late Babylonian tablets written by the scribal apprentices of Babylon. The consignment of 
tablets to which the tablet belongs, accessioned on 6 July 1881, was purchased more than two years earlier from the dealer Joseph M. Shemtob (Reade 1986: xv). Late Babylonian tablets that came on to the market at this time were chiefly from Babylon, where local people were mining the site for them, and it is likely on these grounds too that this city is the provenance of Nabûmušetiq-uddi's tablet. An odd symmetry appears: the text that records the reaction of the scholars of Borsippa to Ashurbanipal's demand survives in a copy from Babylon, while our second text, recording the reaction of their rivals at Babylon, is known from a manuscript found, in all probability, at Borsippa. This is no doubt an accident of discovery. The distribution of exemplars in both sites is symptomatic of the two texts' inclusion in the scribal curriculum. There they joined another Neo-Babylonian letter on the subject of royal tablet collecting, $C T 221$, which will be discussed below, after the editions of BM 45642 and 28825 .

Much of 11. 1-12 has been quoted in a previous article (George 1997: 71-2 with fn. 9). Lines from the text are also cited by Fincke 2004 and by Frahm in press.

BM 45642 (81-7-6, 35). Copy: Fig. 1

top edge: $[i n] a$ a-mat ${ }^{\mathrm{d}} b \bar{e} l(\mathrm{en}) u\left[{ }^{\mathrm{d}} b \bar{e} l\right] t i($ gašan)-iá liš-lim obv.

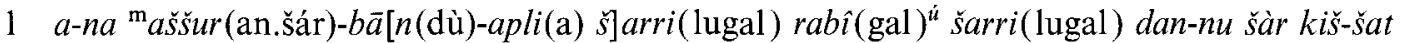

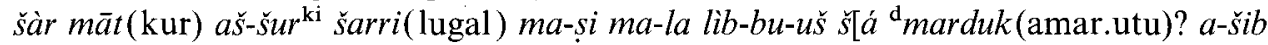
é.sag.gíl?]

$2 \dot{u}$-ma-'-ir-šu-ma šarru(lugal )-ut māt (kur) a ̌̌šsur ${ }^{\mathrm{ki}} i$-qip-pu-uš-šú ú-šat-lim-šú šarru(lugal)-ut

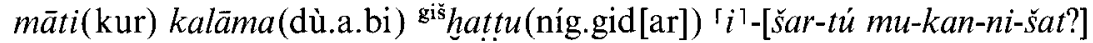

3 la ma-gi-ri qa-tuššsú it-muh-hi uš-pa-ri mu-šam-qit za-a-a-ri imnuš(15)-šú na-ši šá dabû(nà) ${ }^{\top} a^{\top}-\left[{ }^{\top} i b\right.$ é.zi.da]

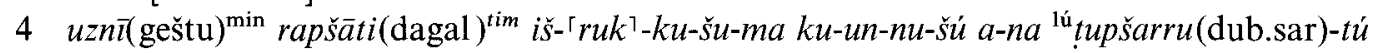
kima (gim) ia-a-ti ni-i[l]-t[ap-ra? um-ma]

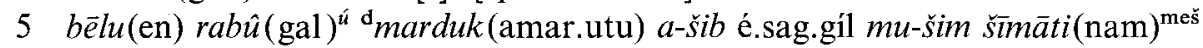
gišshattu(níg.gidar) $i$-šar-tú $u s ̌-p a-r i k i-{ }^{-} i-n i^{1}$

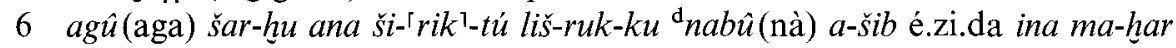
${ }^{\mathrm{d}}$ marduk(amar.utu) a-bi a-li-di- ${ }^{5} u^{1}{ }^{1}$

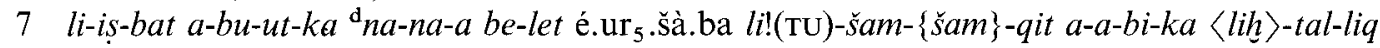
$\mathrm{x}[\mathrm{x}] \mathrm{x}-k u$

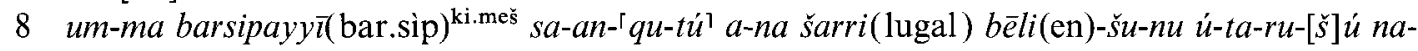
ášs-par-tum šá ${ }^{\top} i \breve{s}-t u-r u^{\top}$

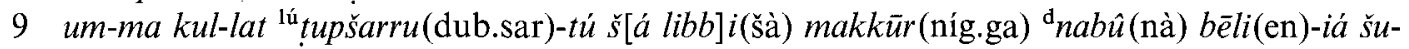
tu-ra-' šu-bil-la-ni

10 šul-li-'-a [na-áśs]-par-t[um min-d] e-e-ma šarru(lugal) ina lib-bi-šú i-ta-me šá kīma(gim) lúm $m \bar{a} r \bar{\imath}(\mathrm{dumu})^{\text {meš }}{ }^{\prime} b \bar{a} b i l i(\mathrm{E})^{\mathbf{k i}} n i^{i}-i[g-g] u$

11 ina lisāni(eme) dalihti(lù) e-nin-ni ina pî (ka) [šarr] i(lugal) bēli(en)-ni ul ni-ig-gu ni-na-h̆u ni-dal-li-pu ana šarri(lugal) bēli(en)-ni nu-šal-lam n[a-áš]-par-tum \{ni\}

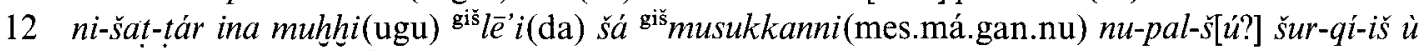
ana muhhi(ugu) gišs le’i(da) šá šumerî(eme.gi $\left.{ }_{7}\right) \operatorname{sâti(\langle ud\rangle .ul.dù.a)~}$

13 šá taš-pu-ru al-la šá ina é.sag.gíl ia-a-nu en-ni ina mahar(igi) šarri(lugal) bēli(en)-ni lim-šal

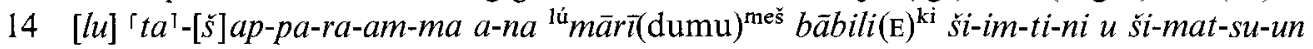

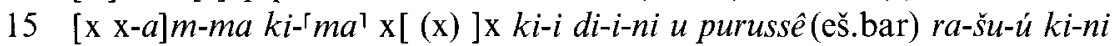

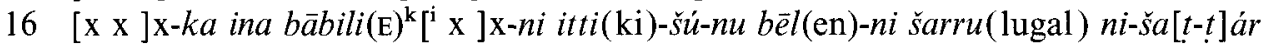

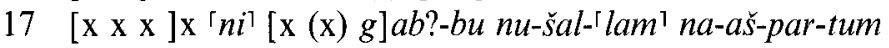

rev.

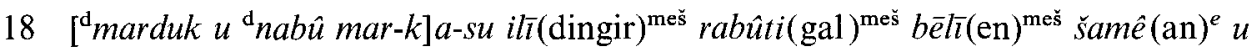
$\operatorname{erseti}(\mathrm{ki})^{i i}\left[{ }^{m} \check{s}\right]$ im-tim damiqtu $\left(\operatorname{sig}_{5}\right)^{t}\left[{ }^{i m}\right]$

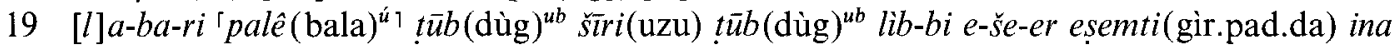
napišti(zi) šarri( lugal)

20 'bè li(en) ${ }^{1}-n i l i-s ̌ i-m u-\dot{u}$ 


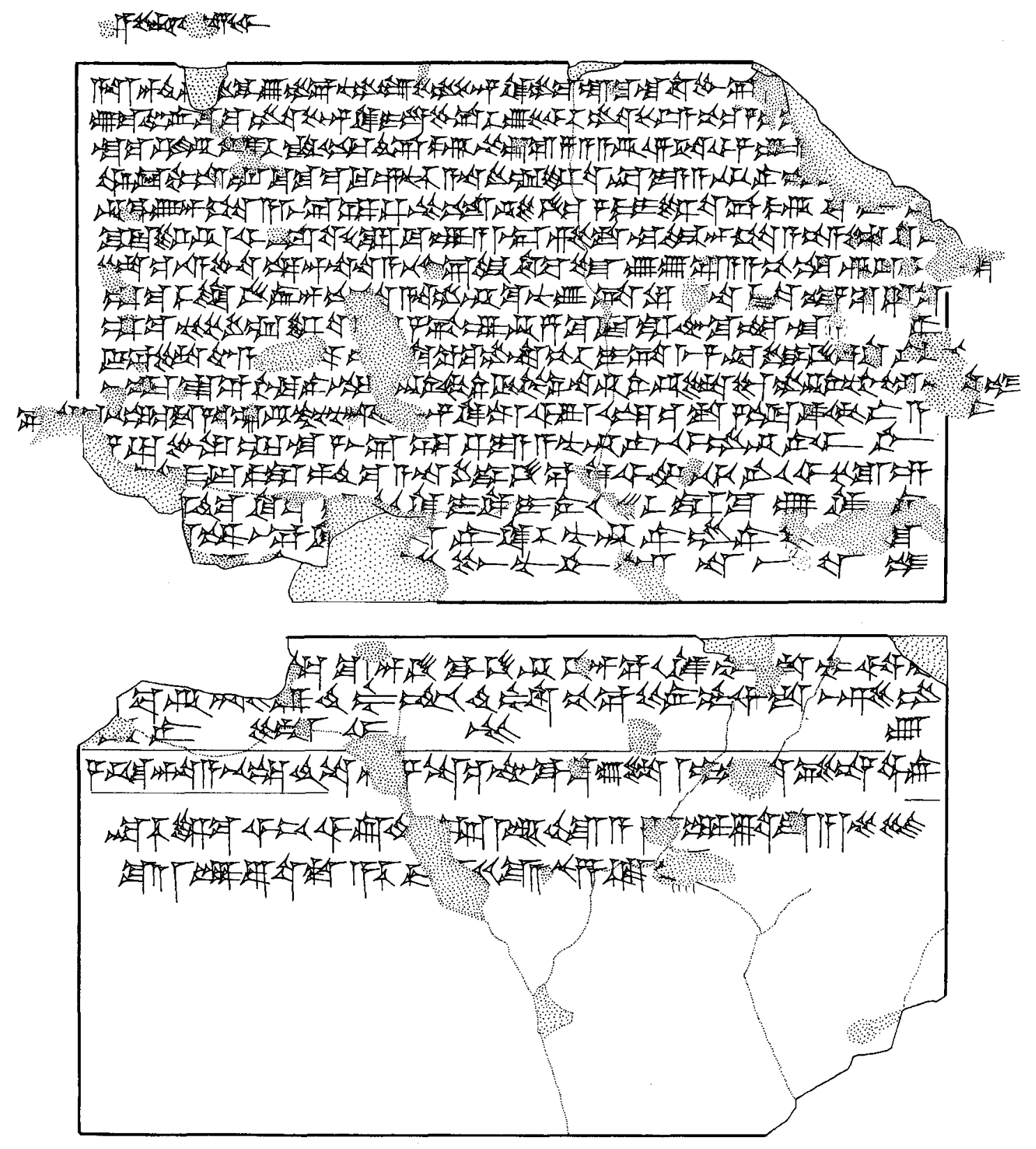

Fig. 1. BM 45642 obv. (top) and rev. (bottom)

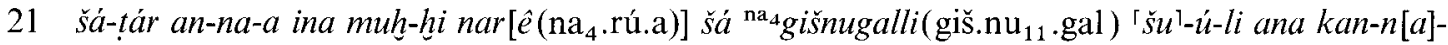
${ }^{\top} a{ }^{\top}$-tú gab-bi šá-pi-ir

$22 k \overline{i m a}(\operatorname{gim})\langle$ labiri $\rangle$-šú šatir(sar)-ma uppuš(igi.tab) u bari(igi.kár) ${ }^{\mathrm{i}}\left[{ }^{\mathrm{m}} t\right]$ uppi(dub) ${ }^{\mathrm{md}}$ bè $l(\mathrm{en})-$ uballiț(tin)-su māri(a) $\check{s ̆ a ́}^{\ulcorner\mathrm{m}}{ }^{\mathrm{d}}$ nabû(nà)-mušêttiq(dib)-uddi(ud.da) $m \bar{a} r$ (a) ${ }^{\mathrm{m}} m u$-še-zib

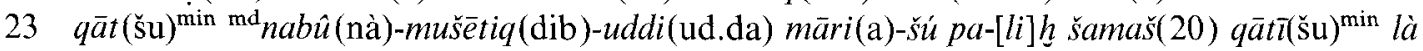
$i-p a \check{s}_{\mathrm{x}}(\mathrm{GÍ} N)-{ }^{\lceil} \check{s}_{i} t^{1}$

By command of Bēl and Bēltīya, let it be a success!

To Ashurbanipal, great king, mighty king, king of the world, king of Assyria, king who can do as he pleases, [to whom Marduk, who dwells in E-sangil, $]^{2}$ gave charge and delegated the kingship of Assyria and (on whom) he conferred the kingship of the entire country, (who) grasps in his 
hand a fair sceptre [that subdues] ${ }^{3}$ the insubmissive, (who) bears in his right hand the staff that lays low the aggressor, on whom Nabû, who dwells [in E-zida,] ${ }^{4}$ bestowed broad understanding and who like me is bowed to the scribal art, we send [word, thus:]

${ }^{5}$ May the great lord Marduk, who dwells in E-sangil and determines destinies, bestow on you as a gift a fair sceptre, a true staff ${ }^{6}$ and a magnificent crown! May Nabû, who dwells in E-zida, intercede for you ${ }^{7}$ before Marduk, the father who sired him! May Nanāy, the lady of E-ur-šaba, lay low your enemy and destroy your [ foe]!

${ }^{8}$ Further: The dutiful Borsippans will send back to the king their lord the instruction that he wrote ${ }^{9}$ as follows, "Write out all the scribal learning in the property of Nabu and send it to me. ${ }^{10}$ Complete the instruction!" Maybe the king says to himself, we (are ones) who, like the citizens of Babylon, will shirk (it) ${ }^{11}$ by (using) confusing language. Now, we shall not shirk the king's command. We shall strain and toil day and night to complete the instruction for our lord the king. ${ }^{12}$ We shall write on boards of sissoo-wood, we shall respond immediately. ${ }^{2}$ And regarding the board in Sumerian, the glossary ${ }^{13}$ about which you sent word, there is none but that in E-sangil. Let enquiries now be made before our lord the king. ${ }^{14}$ [You should] send word to the citizens of Babylon, Our destiny and their destiny ${ }^{15}$ are [...] like [...] that they possess judgements and decisions, (is) true ${ }^{16}[\ldots]$ your $[\ldots]$ in Babylon [...] . . with them, our lord the king. We shall write ${ }^{17}[\ldots] \ldots[\ldots]$ all, we shall complete the instruction.

${ }^{18}$ [May Marduk and Nabû, the] bonds of the great gods, the lords of heaven and underworld, ${ }^{20}$ decree in the life of our lord the king a favourable destiny, ${ }^{19}$ [long] duration of reign, soundness of body, soundness of mind and straightness of bone.

${ }^{21}$ This inscription was copied on to a tablet (or tablets) of alabaster and sent to all the colleagues.

${ }^{22}$ Written according to its original, checked and collated. Tablet of Bēl-uballissu, son of Nabûmušètiq-uddi, descendant of Mušezzib. ${ }^{23}$ Handiwork of Nabû-mušětiq-uddi, his son. He who fears Šamaš must not erase my handiwork.

\section{Notes}

1. The restoration of Marduk äšsib Esangil is suggested on literary grounds, to make a pair with Nabû äšib Ezida in 1. 3. Marduk and Nabû are also paired, each with the same epithet, in 11. 5-6 and restored together in 1. 18. Theologically speaking, the restoration proposed in the present line is inherently plausible, though unparalleled in official documents from the reign of Ashurbanipal. Babylonian ideologues would certainly have maintained that Marduk, not Aššur, conferred the throne of Assyria on Ashurbanipal, for in this period they believed that, as king of the gods, the patron deity of Babylon was the prime mover in all human history. On this account learned scribes of later generations could assert that Marduk commissioned Cyrus of Persia first to destroy the Medes and then to invade Babylonia ( $\mathrm{Nbn} 1=\mathrm{V} R 64$ i $26-9$, ed. Schaudig 2001: 417; Cyrus cylinder $=$ V $R 35+B I N$ II 32: 12-17, ed. Schaudig 2001: 552).

11. The trailing $n i$ at the end of the line is understood as a false start to nišattar, subsequently interpolated on the left margin at the next line.

12. The decipherment of the verb of the second clause is uncertain. A reading nu-bal-šu for nubbalšu "we shall carry for him" is obviously unsatisfactory in the context. We have assumed it to be nuppalšu, i.e. apālu "respond" in the rare II/1 stem. This means "pay off" a debt (OB), "discharge" an obligation (Ras Shamra) and, factitive, "make answerable" (once in NA). It is not known elsewhere in Neo-Babylonian but suits the discharging of the royal commission laid on the scholars of Borsippa. The adverb šurqiš "stealthily" hardly makes sense with either verb; we suspect it is an error for surriš "immediately".

13. In some desperation the last word is assumed to be liššăl (šalu IV/1) with a hypercorrect dissimilation

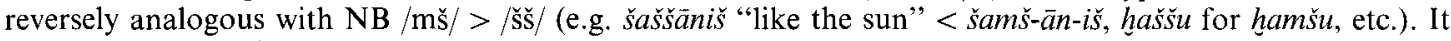
may, on the other hand, be an error.

18. For markasu as an epithet of gods see Tallqvist 1938: 175-6; the allusion is to the control of the cosmic bonds by the most powerful deities (George 1986: 139, 143). In Enūma eliš VII 95 Marduk is hailed in his identity Lugaldurmah as mar-kas ili(dingir) mes "bond of the gods". Our line holds a variant of that epithet but requires a plurality of gods, and the obvious pair is restored.

21. The word $\breve{s u-u}-l i=\breve{s} \bar{u} l$ (for SB stative $\breve{s u} l u$ ) also appears in the rubric of the companion piece (BM 28825: 39). The phrase ina muhhi ... šülu occurs in a colophon preserved on two manuscripts of Uruanna from Kuyunjik (Hunger 1968: No. 321, 16-17): ina sa-di-ri šùm-šú-nu ul im-bi-ma (var. am-bi-ma) ina muhhi(ugu)

\footnotetext{
${ }^{2}$ Tablet (erroneously?): "stealthily".
} 
tuppī(dub) $)^{\text {meš }} \dot{u}$-še-li "I did not cite their titles in the ruled-off section but did enter them on the tablets". Regarding the antepenultimate word, qannātu "horns, fringes" is surely inappropriate; the assumption here is that the word intended by the spelling $k a n-n[a]^{r} a^{l}-t \dot{u}$ was kinattu, a plural of the common NB word for fellows and peers. The use of CVC signs for syllables where the vowel is other than expected is an occasional feature of Akkadian orthography. In the late period it was encouraged by the absence of vowel notation in the alternative, Aramaic writing system.

23. The cryptic spelling of ipašsit also occurs in the colophon of a tablet written at Babylon in the reign of Alexander Balas (SE $164=148 \mathrm{BC}$ ). Hunger's reading $t u_{18}-m a_{9}$-laq (1968: No. 167, 9; also $\left.A H w 1573 a\right)$ was corrected by $C A D \mathrm{M} / 1161 \mathrm{~b}$ s.v. ${ }^{* *}$ maläqu. I. L. Finkel, who kindly drew our attention to this other colophon, knows of further examples of this spelling in the colophons of unpublished Late Babylonian tablets.

\section{Ashurbanipal and the scholars of Babylon}

Regrettably the tablet BM 28825 (98-11-12, 1) is poorly preserved and the exact interpretation of many sections remains uncertain. Nevertheless, it is immediately apparent that the text preserved on it offers further evidence of King Ashurbanipal ordering the copying of tablets in Babylonia for his collections in Nineveh. In the light of the preceding exegesis of BM 45642, the tablet BM 28825 can be identified more particularly as a Late Babylonian copy of a transcript of a letter written on behalf of the scholars of Babylon in response to the king's request for scholarly cuneiform texts.

BM 28825 comes from a collection of over five hundred Old Babylonian and Neo-BabylonianAchaemenid tablets acquired by the British Museum in 1897-8 from the Baghdadi antiquities dealers Asher Salem and Thoma Hindi. The overwhelming majority of the Neo-Babylonian and Achaemenid period economic texts in the collection that record the place at which they were composed indicate that they came from Borsippa (information courtesy C. B. F. Walker). The collection includes a few economic texts from the time of Ashurbanipal and his brother Samaššum-ukīn drawn up at Babylon, Borsippa, and Dilbat: BM 29171 (98-11-12, 347; Borsippa, year 22 of Asb), BM 29105 (98-11-12, 281; Babylon, year 12 of Ššu); BM 29084 (98-11-12, 260) and BM 29086 (98-11-12, 262) (both Dilbat, year 13 of Ššu), and BM 29029 (98-11-12, 205; Dilbat, year 16 of Ššu); see Brinkman and Kennedy 1986: 22 J.18, 29 K.50, 30 K.68 and K.71, and 33 K.107. The ancestor of the scribe/owner of the tablet, ${ }^{\mathrm{md}_{4}} \mathrm{ei}_{7}$-ba-ti.la, also appears in colophons of tablets copied during the Seleucid and Parthian periods (see below, the textual note on 1.40). Two colophons mentioning this individual state that the tablets were copies of originals in Borsippa (Hunger 1968: Nos. 410-11). Thus, although the original provenance of the tablet BM 28825 is not known for certain, it likely came from Borsippa or Babylon. The handwriting of BM 28825 is distinguished by the lack of upper horizontal wedge on signs like $k u, l u, ~ s a r$ and $k i n$ (as also BM 45642), and reinforces a general impression from physical inspection, that the tablet is postAchaemenid.

The tablet is badly damaged, and continuous text is rare, so the reconstruction of its contents must be provisional. With the example of BM 45642 in mind, division into the following passages seems likely:

(a) Address to King Ashurbanipal (11. 1-7, cf. BM 45642: 1-4). The writer places fulsome emphasis on the king's scholarly learning, scribal dedication and generous patronage of the temples of Babylon.

(b) Quotation of the king's command (11. 8-10, cf. BM 45642: 9-10). His demand is for all texts of the Sumero-Babylonian scribal tradition (kullat tupšarrüti gabbi), with specific mention of exorcistic lore, omen compendia and liturgical chants, such as can be found in the great temple Esangil.

(c) Response detailing the Babylonians' reaction to the king's demand (11. 10-18). A team of twelve expert and experienced scholars has been identified and will not delay in setting to work; practical preparations are under way, e.g. of their writing instruments.

(d) Reassurance that the scholars will work diligently (11. 18-20). The writer perhaps anticipates the king's anxieties about their commitment to the task (cf. BM 45642: 10-12).

(e) Further details, making reference to particular scholars and texts (11. 20-4, fragmentary, cf. BM 45642: 12-14). This passage is too damaged to yield connected sense.

(f) Quotation of the king's promise of payment and other rewards (11. 24 36). Much of this passage is also difficult to reconstruct, but clearly Ashurbanipal has publicly promised great benefit to Babylon if his command is obeyed. In particular he will reward the individual scholars very generously in silver for their efforts, and more generally re-establish the Babylonians' exemption from duty (kidinnu).

(g) Date, "the fifth year" (1.36). 


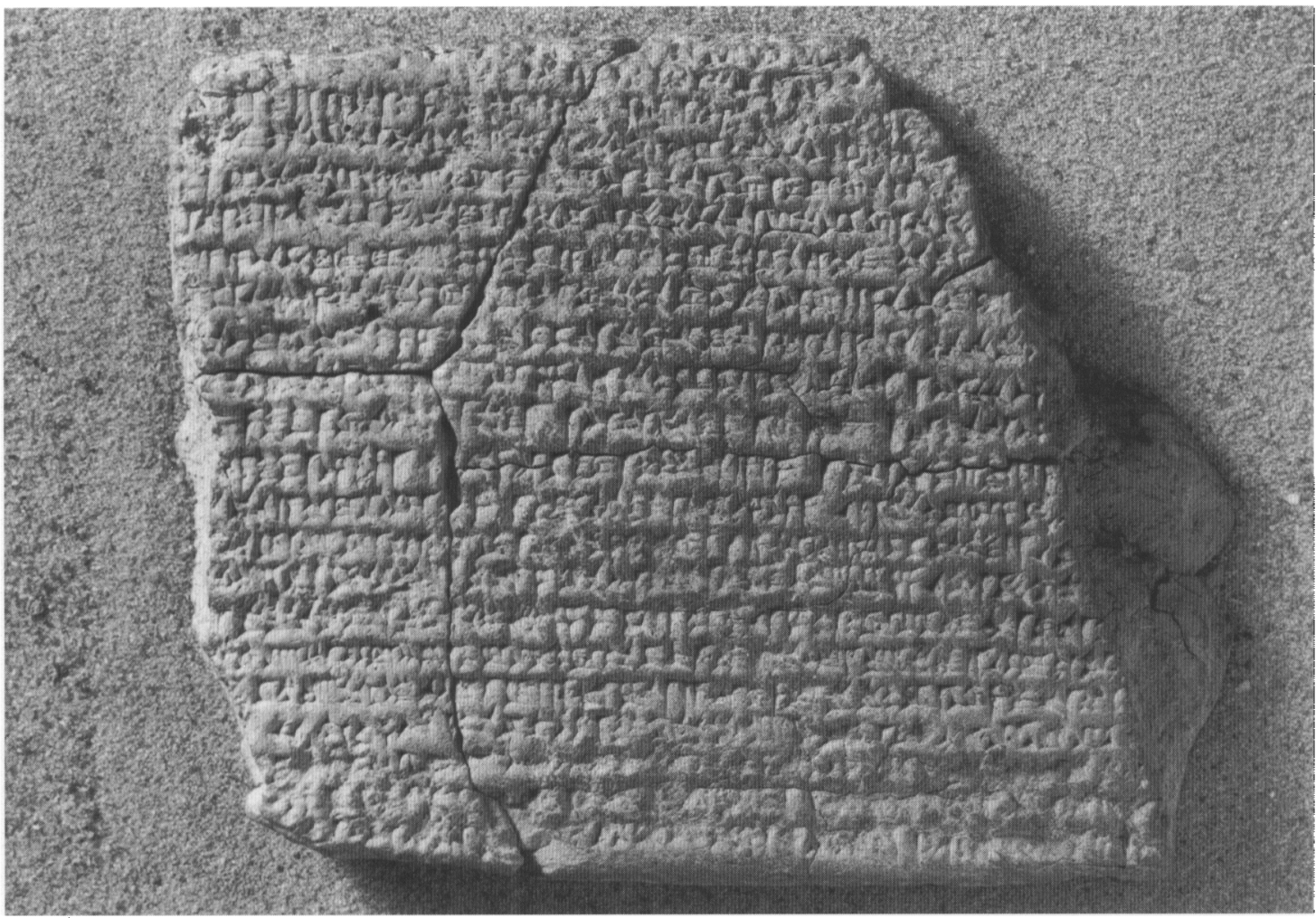

Fig. 2. BM 28825 obv. (CThe Trustees of The British Museum

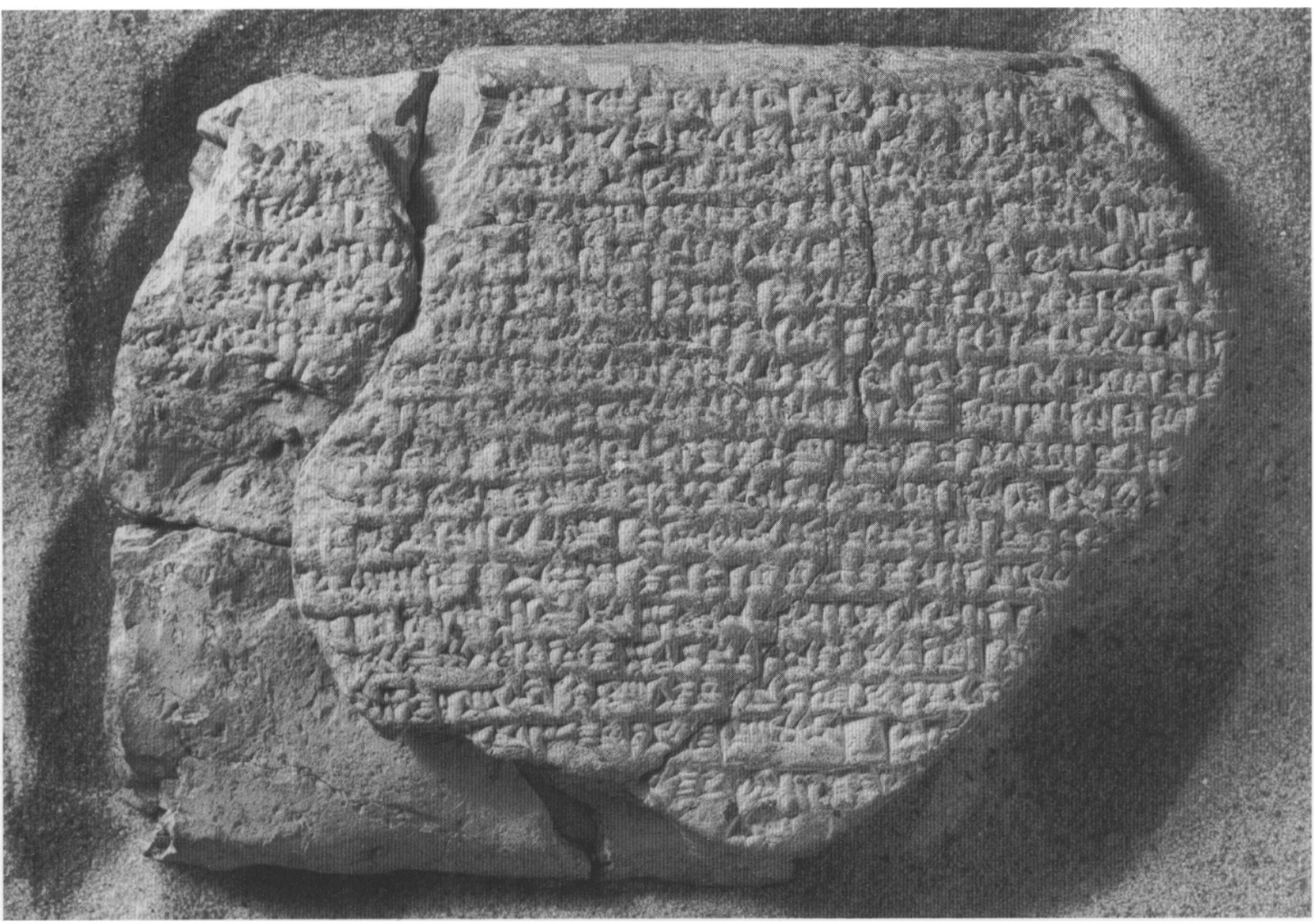

Fig. 3. BM 28825 rev. (O) The Trustees of The British Museum 
(h) Account of the Babylonians' reaction to the king's promises (11.36-8). The writer reports that the king's instruction caused great excitement in Babylon, with some five thousand men gathering to learn the news.

(i) Rubric (1.39, cf. BM 45642: 21). The foregoing text was copied from a writing-board.

(j) Colophon (11. 40-1, ef. BM 45642: 22-3). The tablet belonged to a member of the well-known Egibi family.

As was the case with BM 45642, the original text copied on BM 22825 is no normal letter, but rather a collective formal communication responding on behalf of numerous scholars. Accordingly, while this letter appears to have been sent by one particular individual (cf. "[like] me" in 1.7 and "my lord" in 1.15), his name may not have been given in the expected place in the text. Perhaps, though, it occurred in the damaged portion at the end of the text or in its rubric, where a certain Erra-[...] is mentioned.

This second text also displays a literary style unsurprising in a formal communication of scholars. Particularly striking is the adapted quotation of a line from a scholarly hymn to Ninurta, by which the writer assures Ashurbanipal that the twelve scholars chosen for the task of copying texts for him are as learned as Ninurta himself (for Ninurta as a learned scribe see Annus 2002: 81-90). Compare:

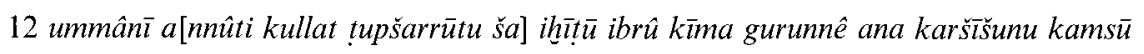

BM 28825: 13-14

These twelve scholars have, stored in their minds like $g$., [the entire corpus of scribal learning that] they have read and collated.

um-man-nu mu-du-u šá ki-ma šá-a-ri a-na me-hi-il-ti i-ziq-qa

u kul-lat ${ }^{\text {lú }}$ tupšarru(dub.sar)-ú-tu kīma(gim) gu-ru-un-né-e ina kar-ši-šú kam-su

Hymn to Ninurta as Helper in Need, 11. 37b-9a, LB MSS (Mayer 1992: 26)

Learned scholar, who "blows like the wind" on cuneiform writing,

and has the entire corpus of scribal learning stored in his mind like $\mathrm{g}$.

This vivid image of the texts stored in the minds of the scholars, perhaps like grain piled in a granary, ${ }^{3}$ points out that the most learned and experienced men are on the job, men who are so good that they have the entire Sumero-Babylonian scribal tradition by heart.

Other examples of Standard Babylonian literary style are found in BM 28825. Non-final verbs occur on numerous occasions:

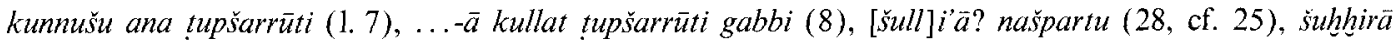
našpartu (29), šullimā našpartu (31), [uša]zzaz kidinkunu, utâb libbakunu, ušapšah kabtatkun(u) (32), [ušad] bab šumkunu, unessēkunūši tupšikku (33), nušaqqâ rē̌š [unu] (35)

Again, there are clear examples of Neo-Babylonian orthography and dialect in BM 28825. For example:

gabbu (11. 8, 15, 30), ni-na-ḩu (19) for SB ninâh, alla (26), eninni (28), šu-țu-ra-' (31) for SB šutrāa úttabi (32) for SB utâb, ri-gim (38) for SB rigmu, šu-ú-li (39) for SB šŭlu; possibly naphar (1) for SB naphari

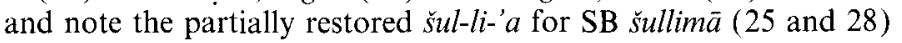

Many of these same forms have already been met in BM 45642. In addition, there are likewise several examples of inflected endings that are not written according to earlier rules.

BM 28825 (98-11-12, 1). Photographs: Figs. 2-3, copy: Fig. 4

obv.

1 [ana Ǎšsur-bān-apli ......]x [(x) na]p?-「har?? bēl(en) x x x[...]

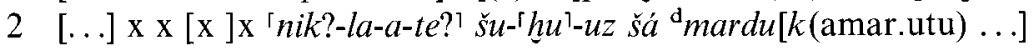

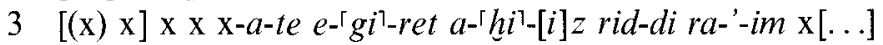

4 [x (x) x-t]um šarri(lugal) en-qa mu-du-ú le-'-é-um šàr māt (kur) aš-šur ${ }^{\mathrm{ki}} a-\mathrm{x}[\ldots]$

$5[\mathrm{x}(\mathrm{x})] \mathrm{x}-{ }^{r} k u^{1} m u$-šar-ru-ú ${ }^{\mathrm{d}} b \bar{e} l i(\mathrm{en}) \operatorname{rab} \hat{\imath}(\mathrm{gal})^{u} \mathrm{~d}$ marduk(amar.utu) ina é.sag.íl x[...]

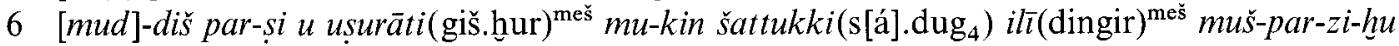
ekurrāti(é.kur) ${ }^{\text {meś }}\left[\right.$ bābiliki ${ }^{\text {ki }}$ sarri bèlīni $\left.\breve{s} a\right]$

7 [kima i] a-a-ti ku-nu ku-ú-un-nu-šú a-na lútupšar(dub.sar)-ru-tum il-[tap-ra-an-na-ši um-ma]

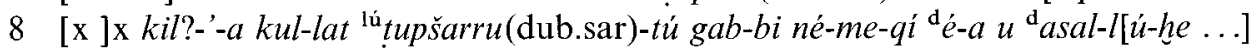

\footnotetext{
${ }^{3}$ On kima gurunne and the syntax of the clause see below, the textual note on BM 28825: 13-14.
} 


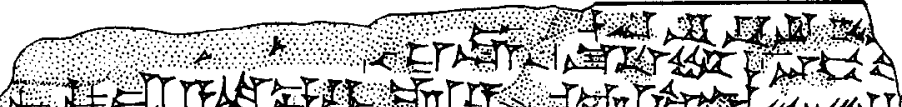

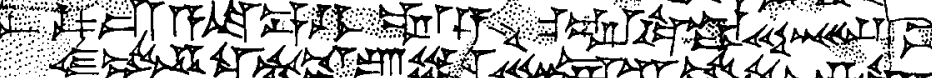

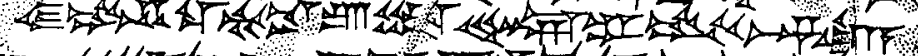

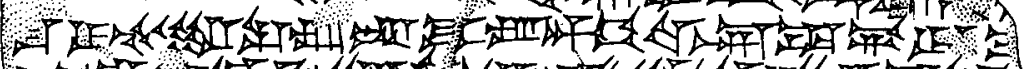

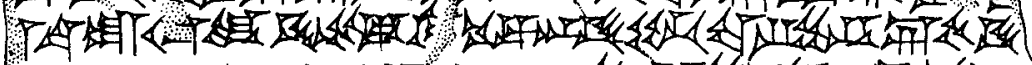

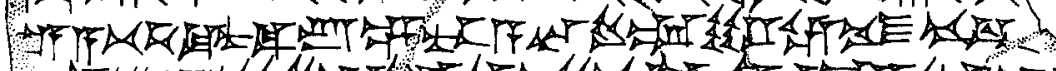

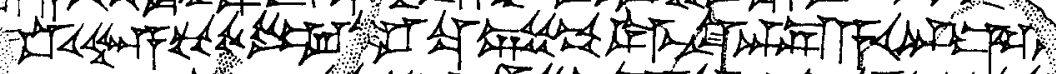

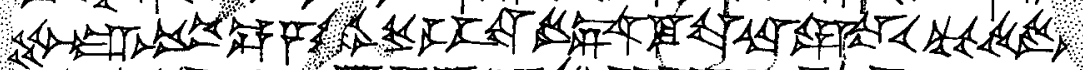
\#LA+

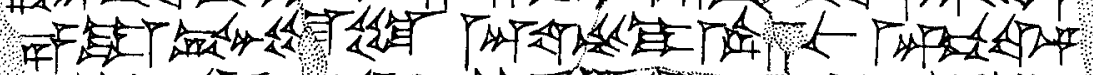

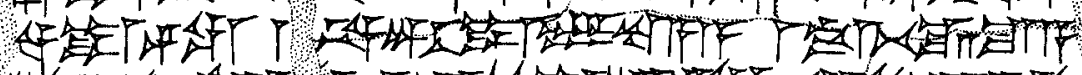

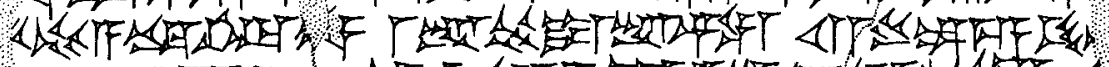

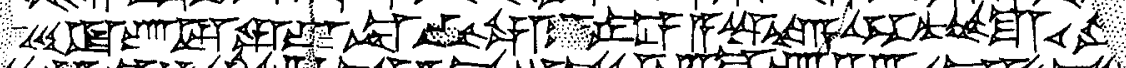

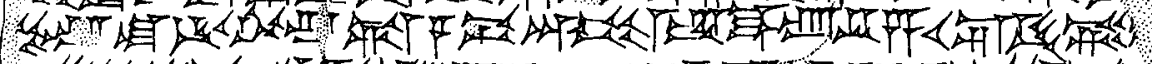

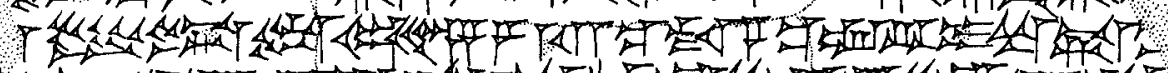

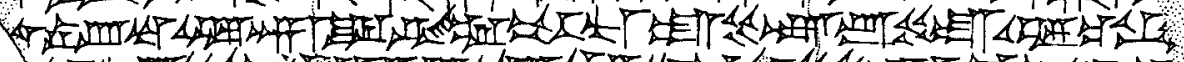

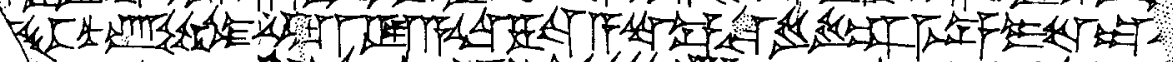

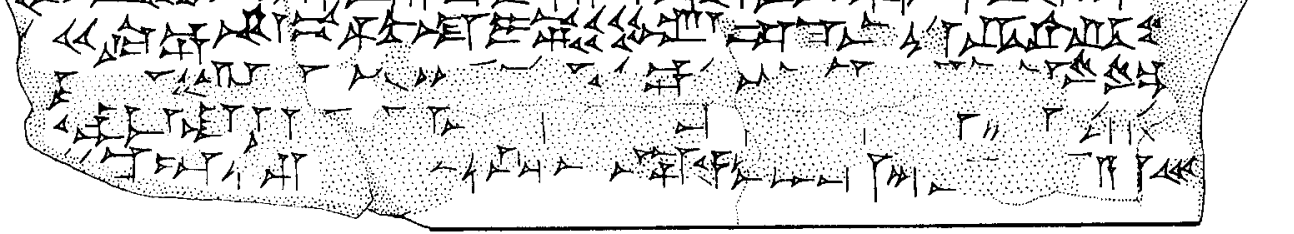

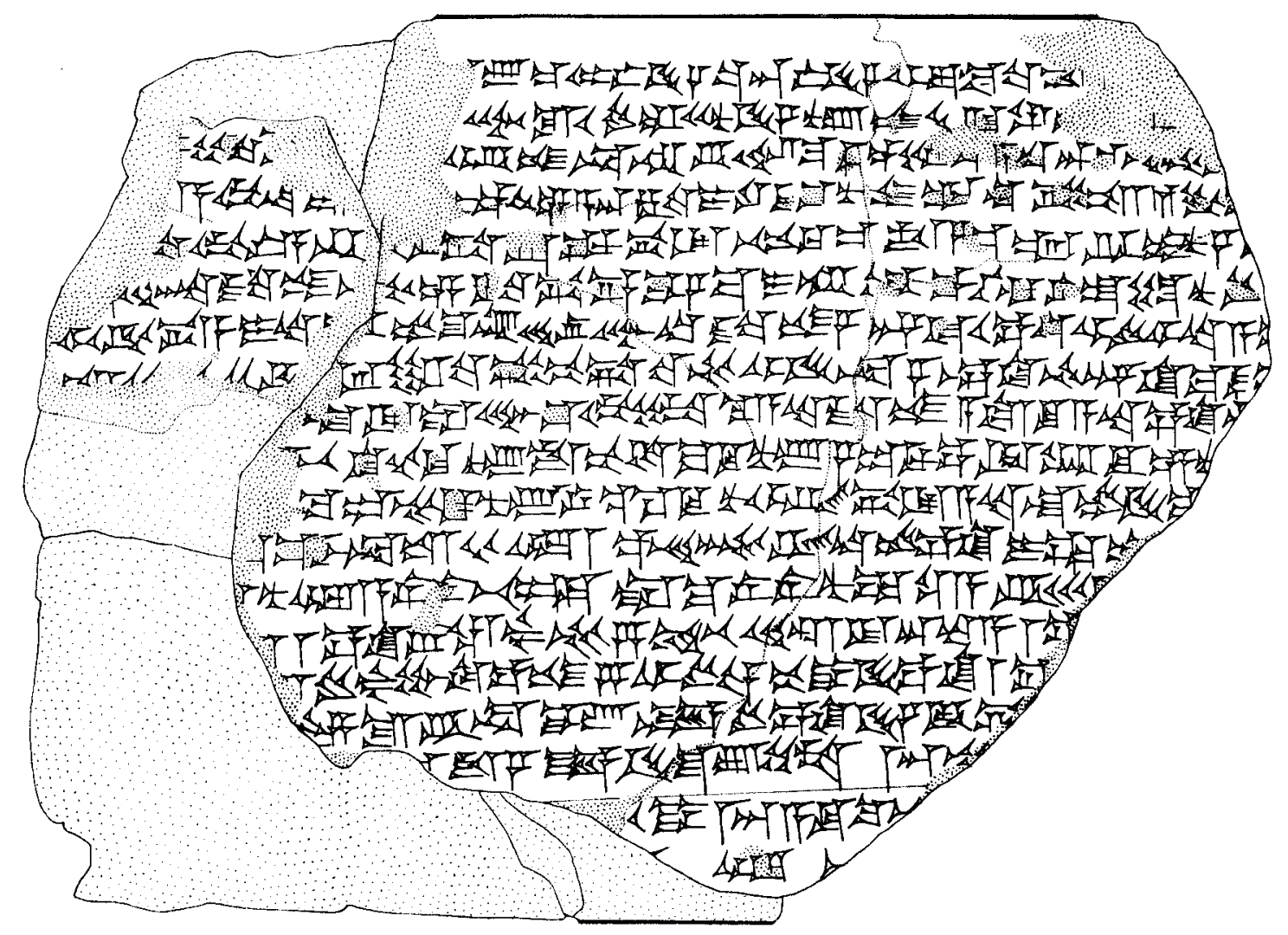

Fig. 4. BM 28825 obv. (top) and rev. (bottom) 


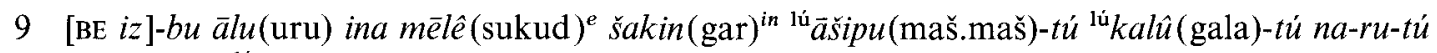
$u$ kul-lat ${ }^{\text {lú }}$ [upšarru(dub.sar)-tú mala bašû $\left.\tilde{s} a\right]$

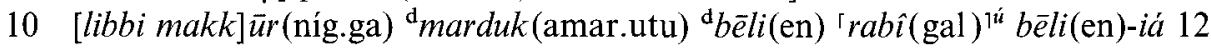
lú ummânīt(um.me.a) $)^{\mathrm{mes̆}} a n-n u-t \dot{u}^{\mathrm{md}} \sin (30)-\bar{e} t i r(\operatorname{sur})\left[m \bar{a} r{ }^{\mathrm{m}} \ldots{ }^{\mathrm{m}} \ldots m \bar{a} r^{\mathrm{m}} \ldots\right]$

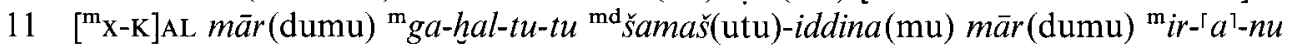
${ }_{\mathrm{md}} \operatorname{marduk}$ (amar.utu)-étír(sur) $\left[m \bar{a} r^{\mathrm{m}} \ldots \mathrm{m} \ldots m \bar{a} r^{\mathrm{m}} \ldots\right]$

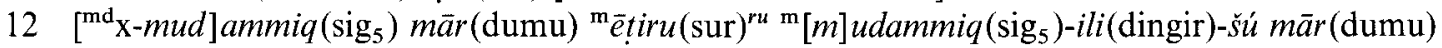
${ }^{\mathrm{md}}$ nabûu(nà)-na-a-a ${ }^{\mathrm{m}}$ ta-bat-qát-su $m \bar{a} r(\mathrm{a})\left[{ }^{\mathrm{m}} \ldots{ }^{\mathrm{m}} \ldots m \bar{a} r{ }^{\mathrm{m}} \ldots\right]$

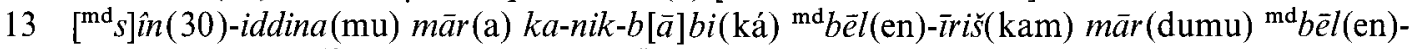

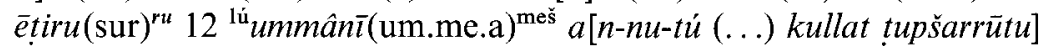

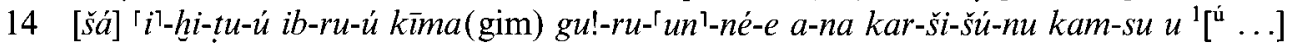

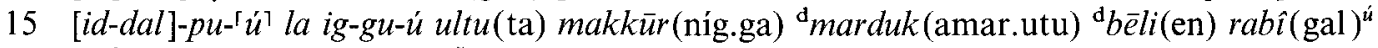
${ }^{\mathrm{d}}$ bèli(en)-iá $u$ bìtăti(é) ${ }^{\mathrm{meš}}$ gab-b $[i \ldots]$

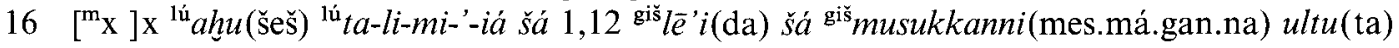
$b[\bar{\imath} t(\mathrm{e}) ? . .$.

17 [šamnu dỉ̉]pu(làl) himêtu(ìnun.na) ù hal-șa ana ruqqi(šen) qan(gi)-țup-pí-šú-nu ana ṣe-pu-ú $\dot{u}$-še-și $\dot{u}$ giš $q \hat{e}$ (sila) ${ }^{1}\left[{ }^{\dot{u}} \ldots\right]$

$18\left[\text { ana } \mathrm{x}^{\mathrm{m}}\right]^{\mathrm{es}}$-šú-nu ú-še-șu ù gì-țu a-na kaspi(kù.babbar) a-na bābili(E) ${ }^{\mathrm{ki}} \check{s} a$ ?(lú) lú ummâñ̄ (um.me.e) i-na-ad-d[in ...]

19 [x x ]x min-de-e ina lib-bi-šú-nu la i-qab-bu-ú um-' ma ni-na'-hu ni-dal-l[i-ip nušallam našpartu?]

$20[\mathrm{x} \times \mathrm{x}] \times \mathrm{x} \times \mathrm{x}$ be? x x x e? x x x x x x lú ${ }^{1 \mathrm{u}} \mathrm{u}[\mathrm{m} . \mathrm{me} . \mathrm{a} \ldots]$

$21[\mathrm{x} \times \mathrm{x}] \mathrm{x} \times \mathrm{la}$ ? $\mathrm{x} \times \mathrm{x} \times \mathrm{x} \times \mathrm{x} \times \mathrm{x} \times \mathrm{x} \times \mathrm{x} \times{ }^{\mathrm{md}} \mathrm{x} \times \mathrm{x}[\ldots]$

$22[\mathrm{x} \times \mathrm{x}] \mathrm{x} \times \mathrm{x} \times[\mathrm{x} \times] \times \mathrm{x} \times \mathrm{x} \times \mathrm{x} \times \mathrm{x}{ }^{\mathrm{md}} \mathrm{x}[\mathrm{x}] \mathrm{x} \operatorname{ma} \bar{r}(\mathrm{a}){ }^{\mathrm{m}} i[m ?-\ldots]$

rev.

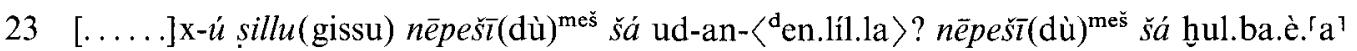
$\left[\begin{array}{llll}x & x & x & x\end{array}\right]$

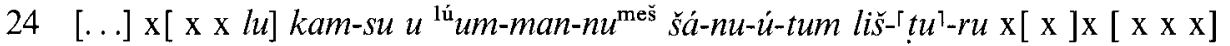

25 [... šu]l?-li? -'[a? na-ášs-pa]-ar-tum kīma(gim) mah-ri-im-ma 1/2(maš) bilat (gú)

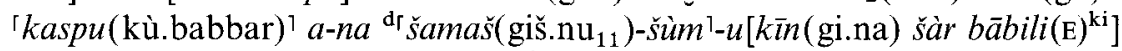

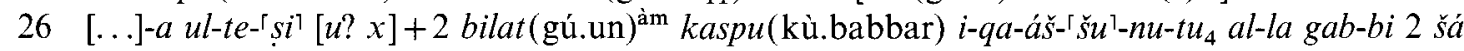
$a h u($ šeš) $t[a-l i-m i ?]$

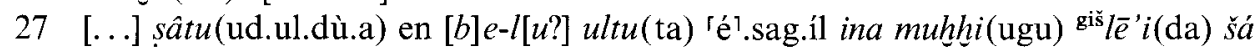
gišmusukkanni(mes.má.gan.nu) šá $\mathrm{x}[\mathrm{x} \mathrm{x}]$

28 [šübilāni? šul?-l]i?-'a na-áš-par-tum 1 (aš) [b]ilat (gú.un) kaspu(kù.babbar) ‘ta-dag'-gal $q \bar{\imath} \check{s} t u$ (níg.ba) i-mah-' har e-nin-ni at-tu-nu lú [ummâñ̄]

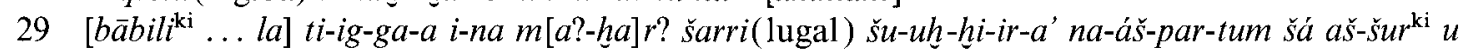
bābili (E) ${ }^{\mathrm{ki}}$ pān(igi) amēli(lú) lem-na $a-\mathrm{x}[\mathrm{x} \mathrm{x}]$

30 [...] x x x x ig? [t]upšarru(dub.sar)-tú gab-bi ultu(ta) $u_{4}-m u$ ninnammaru?(igi) ${ }^{\text {meš }} k \bar{l} m a$ (gim)

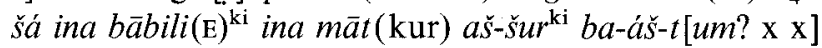

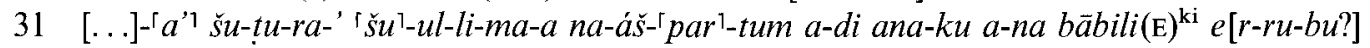

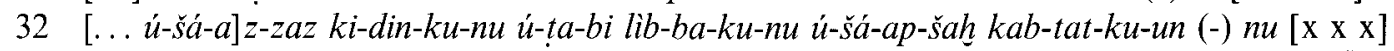

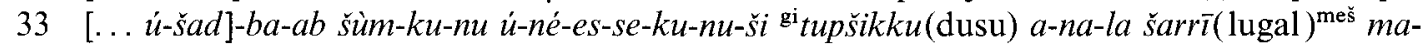
$[a h-r u-t i$ ? $]$

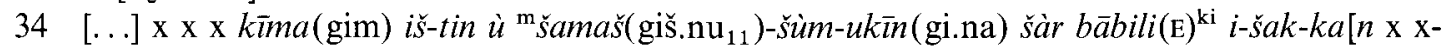
$k u-n u]$

$35[\ldots-k] u-n u$ ù $a-n i-\ulcorner n i\urcorner$ ina mi-lik ra-ma-ni-ni nu-šaq-qa-a re-eš-k[u-nu x x x x]

$36 \quad[. ..] \mathrm{x}$ ana bābili(E) ${ }^{\mathrm{ki}}$ er-ru-ub mu.5.kam!(UZU) ${ }^{\mathrm{im}}$ gi-tu an-na- $a$ ana bābili $(\mathrm{E})\left[{ }^{\mathrm{ki}}{ }^{\mathrm{k}} \mathrm{ki-i} i \mathrm{ik-tal-da}\right.$ ?]

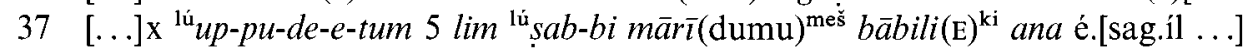

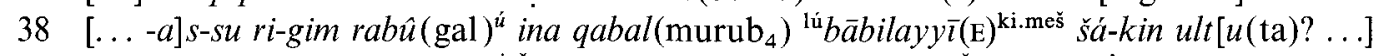

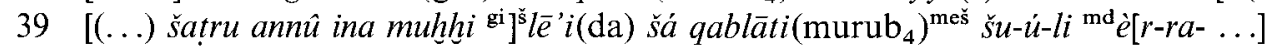

$40 \quad\left[t u p p u \check{s} a^{\mathrm{md}} \ldots m \bar{a} r i \check{s}^{\mathrm{md}} \ldots\right] \mathrm{x} m \bar{a} r(\mathrm{dumu}){ }^{\mathrm{md}} \mathrm{e}_{4} \cdot \mathrm{gi}_{7}$-ba-t[i.la $\left.q \bar{a} t{ }^{\mathrm{md}} \ldots m \bar{a} r \bar{\imath} \breve{s} u ?\right]$

$41 \quad[\ldots$ gi $] \mathrm{m}$ libir.b $[\mathrm{i} \ldots]$ 
[To Ashurbanipal ...] of everything, lord of ... [.. $\left.{ }^{2} \ldots\right] \ldots$ educated in arts of skill, whom Marduk $\left[\ldots{ }^{3} \ldots\right]$ the twisted ... s, who holds to the true path, lover of $\left[.^{4} \ldots\right]$, wise king, expert and learned, king of Assyria, ... [ $\left.\ldots{ }^{5} \ldots\right]$ who has lavished riches on the great lord Marduk in Esangil, $\left[\ldots{ }^{6}\right.$ who has $]$ renewed the rites and ordinances, who has established the regular offerings of the gods, who has provided abundantly for the temples [of Babylon, the king our lord who ${ }^{7}$ like] me is faithfully bowed to the scribal art, (who) wrote [to us thus:]

8 " $[\ldots]$... the entire corpus of scribal learning, the craft of Ea and Asalluhe, $\left[\ldots{ }^{9}\right.$ Summa $] i z b u$, Šmma ălu ina méle šakin, the exorcistic corpus, the lamentation corpus, the song corpus, and all the scribal [learning, as much as there is, that is in ${ }^{10}$ the] possession of the great lord Marduk, my lord."

These twelve scholars - Sîn-ētir [son of $\mathrm{PN}, \mathrm{PN}_{2}$ son of $\mathrm{PN}$, ] ${ }^{11} \mathrm{PN}_{3}$ son of Gahal-Tutu, Šamašiddina son of Ir'anni, Marduk-êtir [son of $\mathrm{PN}, \mathrm{PN}_{6}$ son of $\mathrm{PN},{ }^{12} \ldots$...-mudammiq son of Etiru, Mudammiq-ilīšs son of Nabûnnaya, Țābat-qāssu descendant of [PN, $\mathrm{PN}_{10}$ son/descendant of PN,] ${ }^{13}$ Sîn-iddina descendant of the Door-Sealer, Bēl-ïriš son of Bēl-êtiru — these twelve scholars have, stored in their minds like goods piled in a magazine (i.e. they know off by heart), [the entire corpus of scribal learning ${ }^{14}$ that $]$ they have read and collated, and the $\left[\ldots,{ }^{15}\right.$ they have toiled day and] night (writing it all down); they shall not shirk, from the property of the great lord Marduk, my lord, and all the houses in [... PN] my dear brother, who [...] seventy-two writing-boards of sissoo-wood from the [house (or temple) $\ldots{ }^{17}$ ] he (or I) got out [oil,] syrup, ghee and pressed (oil) to soak the kettle of their styli, and a one-litre vessel of the [...] ${ }^{18}$ he (or I) got out [for] their [ ... ] and the chief scholar will exchange the tablet (credit-note?) for silver at Babylon.

$\left[\ldots{ }^{19} \ldots\right]$ For sure, must they not say in their hearts as follows, "Let us strain and toil day and [night to complete the king's instruction"? $\left.{ }^{20} \ldots\right] \ldots$ the chief scholar $\left[\ldots{ }^{21} \ldots\right] \ldots$ PN $\left[\ldots{ }^{22} \ldots\right]$ ... PN son of PN [... ${ }^{23} \ldots$...] shadow, rituals of UD-AN (= Enūma Anu Ellit?), rituals of Hulba-ea $\left[\ldots{ }^{24} \ldots\right.$ let $]$ them be collected up and let the other scholars write (them) out.

[As regards what the king my lord wrote further, 25 “....] complete [the] instruction! As before half a talent of silver for Šamaš-šum-[ukīn, king of Babylon, ${ }^{26}$... ] I have fetched out. He will give them $[x]+2$ talents of silver each. Over and above everything (else), there are two (or 120?) (talents?) that [my dear] brother ${ }^{27}[. .$.$] The glossary en =b \bar{e} l u$ from Esangil, on a writing-board of sissoo-wood that $\left[\ldots{ }^{28}\right.$ send to me! Compl]ete the instruction! You will own one talent of silver, you(! tablet: he) will- receive a gift! Now, you [scholars of ${ }^{29}$ Babylon, ... do not] shirk, present the instruction before the king! Regarding Aššur and Babylon the face of a wicked man ... [... $\left.{ }^{30} . ..\right]$... all the scribal learning from the day we meet. As in Babylon, so in Assyria honour [... ${ }^{31}$... .] write out! Complete the instruction! As soon as I [come] to Babylon, ${ }^{32}$ [... I shall] establish your protected status, I shall please your hearts and set your minds at ease $\left[\ldots{ }^{33} \ldots\right.$ I shall make all people] speak of your fame, I shall remove from you the hod-basket, more than kings [of old, $\left.{ }^{34} . ..\right]$... are as one, and Šamaš-šum-ukīn, king of Babylon, will establish [your ... ${ }^{35} \ldots$ ] your $[\ldots]$ and we, by our own counsel, shall take care of [you ... $\left.{ }^{36} \ldots\right]$ shall enter Babylon. The fifth year."

[When] this tablet [came] to Babylon, ${ }^{37}[\ldots]$ the temple overseers, five thousand men, citizens of Babylon, [went] to E-[sangil ... ${ }^{38} \ldots$... . . . a great shout went up among the Babylonians, from [...]

${ }^{39}$ [This document] was copied [from a] writing-board of the middle parts. Erra-[...]

${ }^{40}$ [Tablet of PN, son of PN,] descendant of Egi-ba-tila. [Handiwork of PN his son(?). ${ }^{41}$ Written according] to its original, [checked and collated ...]

\section{Notes}

5-6. It is appropriate that Ashurbanipal's benevolent acts toward Marduk and Babylon are mentioned in the address since the letter is from Babylon and deals with the copying of tablets belonging to Marduk. Upon his succession in 669 Ashurbanipal completed the reinstatement of the religious buildings and cults of Babylon, begun by his father; his deeds are described in numerous royal inscriptions from Babylonia and Assyria (e.g. RIMB 2198 B.6.32.1: 11-16 "I (re)confirmed the regular offerings for Esangil and the gods of Babylon. I (re)-established the privileged status of Babylon ... I decorated Esangil with silver, gold, (and) precious stones and made Eumuša glisten like the stars of the firmament").

7. Cf. BM 45642: 4, which offers a slightly different version of the phrase: kunnušu ana tupšarrüti kìma $y \bar{a} t i$. Here the signs $k u-n u$ are taken as a II/1 subjunctive stative $k \bar{u} n u$; alternatively they represent a false start to kunnušs. 
8. As we understand the text, the first word of the line should be a plural imperative verb, comparable with BM 45642: 9, where the corresponding command reads kullat tupšarrūti ša libbi makkūr Nabû bēlìya $\check{s} u t(u) r \bar{a} s \bar{s} b i l a \bar{a}$. Neither of these two verbs fits the traces here, nor does any roughly synonymous verb, e.g. $\check{s i t e}$ " $\hat{a}$ or $\check{s} \bar{u} l i ' \bar{a}$. A reading kil! -'-a "hold back" is contextually unlikely (as well as Assyrian in form); [pān $\bar{u}^{\prime} a$ $\left.{ }^{8} \check{s} u-u\right] d !-g i l !-'-a$ (for $\check{s} u$-ud-gil-a-') "place at my disposal" would yield better sense, but in both decipherments the sign read $\mathrm{kil} / \mathrm{gil}$ has one more wedge than is expected in this script. Altogether, there are too many uncertainties to allow confidence.

9. One might expect bārûtu, "the extispicy corpus", not narûtu, "the song corpus", since the former is well attested and the latter is not. In Assyrian library records the series bārûtu is frequently mentioned, along with three of the other series mentioned in this line, Šumma $\bar{a} l u$, Izbu and $\bar{A} \operatorname{sip} \bar{u} t u$ (Parpola 1983: 6 and see below). However, the first sign is certainly a better na than ba; compare na in $11.712,14,16$, etc. and $b a$ in 11. 23, 28, 30, 32, 33, 40. Since a prebend of the musician of Bēl is attested at Babylon in the Neo-Babylonian period (see Wunsch 2003: No. 33: 14; reference courtesy Cornelia Wunsch) and since music was performed during religious rites in Esangil, it would not be surprising if there was a corpus of material dealing with music kept in that temple. The preceding category, kalutu, is also musical.

10-13. It is not possible to identify any of the scholars mentioned here with individuals appearing in other texts with any degree of certainty. SAA XI $156(=A B L 447)$ mentions several individuals with Babylonian names copying texts and Parpola believes that these individuals were Babylonian prisoners being educated in Assyria and instructed in the "Assyrian way of life", with the intention that they would one day enter the Assyrian king's service and take up positions back in their native country (Parpola 1972: 33). One of these is a Šamaš-iddina (r. 15) who could conceivably be the Šamaš-iddina of BM 28825: 11, but since no patronymic is given in $S A A$ XI 156, this must remain doubtful. $S A A$ X $160(=A B L 1321+C T 5457+C T$ 54 106), a Babylonian letter from one Marduk-šāpik-zēri, lists twenty able scholars who could be of use to the Assyrian king, but the names of many of the individuals are not preserved and none that is extant can be found in our text.

11. Cf. the Nergal-êtir son of Gahul-Tutu (' $\left.{ }^{\mathrm{m}} g a-h u^{\prime} l-{ }^{\mathrm{d}} t u-t u\right)$ of $S A A$ VIII 266 r. 6 ( = RMA 123); the paternal name is understood to be Gahul-Marduk in $P N A 1 / 2419$ and 2/2 945, but cf. $P N A 1 / 2418$ sub Gahal. Nergal-êtir was the sender of many Babylonian astrological reports.

12. The final name, Tāäbat-qāssu, is unparalleled as a NB personal name; it is a reversal of the name of a minor chthonic deity, Ereškigal's servant Qässa-țābat (SB Gilgameš VIII 164-5).

13-14. The restoration of kullat tupšarrūti follows the Hymn to Ninurta as Helper in Need (passage quoted in the introduction). There and here this phrase is the adverbial qualifier of ina/ana karššsu(nu) kamsu, literally "he is/they are stacked in his/their mind with all scribal learning". In discussing the problematical simile kima g. as it appeared in the Hymn to Ninurta, Mayer noted the variants (a) ${ }^{\mathrm{gi}} g \boldsymbol{u}-\boldsymbol{r} u$-um-me-e (Sultantepe MS) and (b) gu-ru-un-né-e (two LB copies) (Mayer 1992: 41). These variants are booked in AHw under gurumm/nnî "Rohrgegenstand" (hapax legomenon, p. 1557); Mayer pondered the two variants as evidence for two different words and, noting the context, suggested respectively (a) a reed container and (b) goods (e.g. grain) stored in a magazine or granary $\left(\sqrt{g r n},{ }^{*}\right.$ purussa $\left.{ }^{\prime}\right)$. The determinative of the Sultantepe variant may turn out to be a mirage created by a careless scribe; in translating we have preferred the LB form. Those who prefer not to create another hapax may wonder whether $g u$-ru-un-né-e is not an alternative plural form of the common noun gurunnu "pile" ( $q /$ gurunnu in $A H w)$, normally formally fem. gurunnāe $\bar{e} t i$. The sense of the simile would then be little different. The first sign of the word in BM 28825 is miswritten and could equally be $q u$ as $g u$, but given the evidence of the hymn, where the LB manuscripts agree on $g u r u n n \hat{e}, g u$ is more probable.

15. For the translation of $\overline{l a}$ igg $\hat{u}$ as a negative assertion rather than a prohibition, see Woodington 1982: 323; cf. also lā iqabbû in 1. 19.

16. Since Ashurbanipal frequently called his brother Šamaš-šum-ukin ahu tatìmu, we might assume that the latter is being referred to; however, there is not sufficient room to restore that name at the beginning of the line and the person speaking appears to be the author of the letter, not Ashurbanipal. The "dear brother" would therefore seem not to be Šamaš-šum-ukīn, unless we emend talimiya to talimmika.

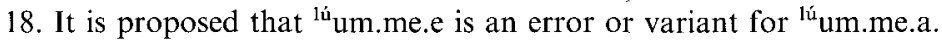

19. Here $l \bar{a}+$ present tense cannot be a negative assertion (as $l \bar{a} \operatorname{igg} \hat{u}$ in 1.15 ), for so construed the news would be the opposite of what the king would wish to learn; accordingly this is a question, to the effect "how can they refuse to obey?" For the restoration at the end of the line, see BM 45642: 11 .

23. It is assumed here that UD-AN is an otherwise unattested abbreviation of the title of the series Enüma Anu Ellil or a defective writing of that title. For the various writings of the name of the series Enuma Anu Ellil, see Parpola 1972: 26 and 1983: 23. Alternatively the reference is to "rituals of Oannes", reading $\bar{u} m$ (ud)ani(an). The series Hulba-ea is not known to us; its name recalls the well-known incantation series Hulbazizi (edition expected from I. L. Finkel).

25. The NB form $\breve{s} u l l i ' \bar{a}$ for $\breve{s} u l l i m \bar{a}$ is also found in 1.28 (mostly restored) and BM 45642: 10; cf. šullimāa in 1.31 .

25-8. These lines suggest that that the scholars were each to receive a large amount of silver for their work. The amounts mentioned here are enormous and, due to the poor state of preservation of the passage, it is difficult to understand the situation with any degree of confidence. 
25. ... As before half a talent of silver for Šamaš-šum-[ukīn, king of Babylon]

26. [...] I have fetched out. He (Šamaš-šum-ukin?) will give them (the twelve scholars?) $[x]+2$ talents of silver each.

26-7. Over and above everything (else), there are two (or 120?) (talents?) that [my dear] brother [...] ...

28. [send to me! Comple]te the instruction! You will own one talent of silver, you(!) will receive a gift! ...

How could Šamaš-šum-ukīn distribute two or more talents to each scholar $(1.26)$ when he appears to have received only half a talent (1.25)? Perhaps we should emend $1 / 2$ in 1.25 to GÉŠ (=60), or bilat "talent" (1. 26) to a smaller unit, i.e. mana or šiqil.

27. The glossary en = be lu may be a commentary to the pirsu 29/30 of $A a$ (see $M S L$ 14: $425-6$ and cf. $S p T U 254$ and p. 2101.56 ); suggestion by Antoine Cavigneaux. As noted earlier, it is possible that this glossary is mentioned in the companion piece, where the Borsippans refer the king to a rare glossary kept only in Esangil (BM 45642: 12-14).

29. Cf. $A B L$ 287: 8'-9' en-na a-na massarti(en.nun)-ku-nu la te-eg-ga-a-" "Now then, don't shirk your watch duty!" (letter of the Assyrian king to the people of Nippur). There does not appear to be sufficient space for the reading $m[a-h a] r$, but no other suitable restoration comes to mind.

The translation assumes that šuhhirā stands for Bab. šumhiră; cf. NA ihhur for Bab. imhur, tahhur for Bab. tamhur, ittahar for Bab. imtahar, etc. $(C A D \mathrm{M} / 151)$. Note that šbhira is not a pure Assyrian form, for the first vowel has not changed to /a/ as it should (*sapris). It is instead a mixed Assyrian-Babylonian form of the kind found occasionally in the Standard Babylonian written in Assyria (e.g. George 2003: 436). While the present letter is written in Babylonian, this passage is a quotation of what the Assyrian king had said, and a mixed form at this point is thus understandable.

32. Ashurbanipal claims to have confirmed the privileged status of Babylon in some of his royal inscriptions (see above, the textual note on 11.5-6), and in consequence the grateful people of Babylon state in a letter to him, "ever since the kings, our lords, sat on the throne, you have been intent on securing our privileged

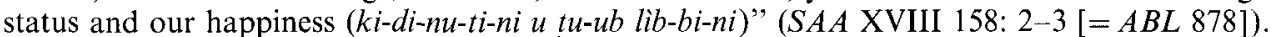

33. Cf. $S A A$ XVIII 158 r. 5' (=ABL 878) al-la šarrāni(lugal) meš mahl-ru-ti "more than past kings".

34. Cf. $A B L 287$ r. 14-15 tabtu(mun) śa gab-bi-ku-nu ki-i 1-en ina muh-hi-iá "the kindness of all of you is as one to me".

36. It is not certain whether mu.5.kam!(UzU) goes with what precedes it or with what follows. Since some Assyrian decrees end with the date (e.g. $S A A$ XII 69,71 and 74 ; month $>$ day $>$ eponymy), it is tentatively assumed to be part of the order sent by Ashurbanipal, even though it follows the Babylonian practice of dating by means of regnal years.

39. With regard to $\breve{s} u-u$-li see the note on BM 45642: 21

40. This is the full form of the family name Egibi, explained as Sîn-taqī̌sa-liblut in $5 R 44$ iii 20 (53), a list of ancestors; see Lambert 1957: 13 and Wunsch 2000: I 1-2 n. 3. As mentioned earlier, colophons mentioning Egi-ba-tila as ancestor of the scribe are known from both the Seleucid and Parthian periods (Hunger 1968: Nos. 144 [composed at Babylon] and 170 [name heavily restored]; see also No. 181 [name partially restored], for the date of which see Neugebauer 1955: 15 and 21). This spelling of the name does, however, appear already in Neo-Babylonian times (for example, Wunsch 2000: No. 7 1.16, reign of Neriglissar). While the Egibi family is best attested at Babylon and Uruk, members are also found at other cities, including Borsippa.

For the tentative restoration of the line, see for example BM 45642: 22-3 and Hunger 1968: Nos. 410-11.

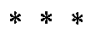

\section{Ashurbanipal and the libraries of Nineveh}

The importance of the documents edited here lies in their implication that in collecting texts for his library Ashurbanipal used commissioned labour alongside involuntary labour and other types of coercion. This is an addition to the range of tactics he is known to have employed in building up the royal holdings. The following discussion will reconsider the evidence for these tactics, which is supplied by (a) library records from Ashurbanipal's reign, (b) seventh-century court correspondence, (c) his own inscriptions and colophons and (d) later scribal tradition. Under the last heading we will assess the significance of the new sources as evidence for Ashurbanipal's tablet collecting.

Library records. Several fragmentary administrative lists document the transfer of private scholars' tablets to Nineveh during the reign of Ashurbanipal, especially an enormous influx of Babylonian tablets and writing-boards soon after the failure of Šamaš-šum-ukīn's revolt in 648, which may have been war reparations. About twenty years ago Simo Parpola published an important study of these fragments and identified them as listing tablets and writing-boards in the process of 
TABLE 1. Text categories in the Kuyunjik library records

\begin{tabular}{|c|c|c|}
\hline Category of text & $\begin{array}{l}\text { Number of } \\
\text { mentions in } \\
\text { the records }\end{array}$ & $\begin{array}{l}\text { Number of tablets and } \\
\text { writing-boards }\end{array}$ \\
\hline Exorcists' lore $(\bar{a} s ̌ i p \bar{u} t u)$ & 9 & at least 18 tablets and 1 board \\
\hline Astrological omens (Enūma Anu Ellil) & 8 & at least 107 tablets and 6 boards \\
\hline Teratological omens $(i z b u)$ & 8 & 10 tablets and 10 boards \\
\hline Terrestrial omens ( $\bar{A}$ lu ina mèlê šakin) & 6 & at least 79 tablets and 1 board \\
\hline Medical recipes (bultēe & 5 & at least 6 tablets and 24 boards \\
\hline Dream omens (iškār Zaqīqu) & 4 & at least 22 tablets \\
\hline Haruspical omens (bārututu) & 3 & at least 135 boards \\
\hline
\end{tabular}

accession into the royal collections (Parpola 1983; see $S A A$ VII 49-56 for more recent editions of these texts and one additional one; also Lambert 1976, Lambert 1989: 95-6, $98 \mathrm{~K} 10182+19757$, and Lambert 1992: 95-6 K 18436+11922 and K 1409+1468). Parpola (1983: 6) noted that the three best-preserved texts studied by him recorded the following text categories in the largest numbers: exorcists' lore, astrology, teratology, terrestrial omens, medical recipes, dream omens and haruspicy (see Table 1).

Over twenty other texts and types of texts are mentioned in those records, including on two or more occasions the menological series Iqqur ipuš, funerary offerings (kispu), commentaries (mukallimtu), lamentation lore (kalûtu) and anti-witchraft rituals (ušs. $\check{1}_{12}$.búr.da.meš). Some of these texts are specifically stated to have come from Babylonia or from individuals from Babylonian cities: e.g. Enūma Anu Ellil, lamentation lore and dream omens from an exorcist from Nippur; antiwitchcraft material from the scribe of the king of Babylon; and haruspical omens from the town of Bìt-Ibâ (Parpola 1983: 14 No. 1 section 5, 18 No. 2 section 4, 20-1 No. 3 section 1). Two of the records date to the end of the eponymy of Belšunu (early 647), thus shortly after the fall of Babylon and the end of Šamaš-šum-ukīn's revolt (Parpola 1983: 15-16 No. 1, 21 No. $3=S A A$ VII 49 and 51), and may include items confiscated from defeated rebels (Parpola 1983: 11). The categories of texts mentioned in these records are, in general, the types of texts that have been found at Nineveh on tablets displaying colophons of Ashurbanipal.

Court correspondence. Many original seventh-century letters and records found at Nineveh mention the copying or collecting of tablets for use by or for the Assyrian king and his scholarly advisers. A few instructive examples follow:

(a) Letter attributed to Akkullānu, dated by Parpola to $c a 655$

[Concerning] the tablets of [the series ... and] the non-canonical tablets [... of which] I s[poke] to the king, my lord, they have now been brought. [If] it pleases [the king], m[y lord], let them $b$ [ring them in, and let the king, my lord], have a look. Later [I shall collect] the Akkadian [writing-b]oards $[\ldots]$ and the Assyrian [writing-board]s [...], and I shall write the tablets [...] ... [And concerning what the k]ing, my lord, [wrote to me]: "Let [all the omens] be e[xtracted]" - should I at the same time [copy] the tab]let of non-canonical [omens of wh]ich [I spoke? Or should I write them] on a secondary tablet? [Wh] at is it that the king, my lord, [orders]?

$S A A \times 101: 2-10$ and r. $1-6(=C T 53187)$

(b) Memorandum of individuals doing scribal work

Ninurta-gimillī ... has completed the series and has been put (back) in irons ... Kudurru and Kunaya have completed "Evil Demons" ... These nine have been serving with the scholars and are working on "Sick Man's House" ... These three are finishing the series according to its (original) tablet.

$S A A$ XI 156: 8-9, 14-17, r. 10-14, 18-20 (=ABL 447)

(c) Letter of Ninurta-ah-iddin

Let me read the tablets in the presence of the king, my lord, and let me put down on them whatever is agreeable to the king; whatever is not acceptable to the king, I shall remove from them. The tablets I am speaking about are worth preserving until far-off days.

$$
S A A \times 373 \text { r. 4-13 (=ABL 334) }
$$

(d) Letter of Marduk-šăkin-šumi, dated by Parpola to 671-X-13

(As) the king, my lord, knows, an exorcist has to avoid reciting a "hand-lifting" prayer on an evil day: (therefore) I shall now look up, collect and copy numerous - twenty to thirty - canonical and 
non-canonical tablets, (but) perform (the prayers) (only) tomorrow evening and on the night of the 15 th day.

$S A A \times 240: 20-$ r. $2(=A B L 23)$

(e) Letter of [Marduk-šākin]-šumi, dated by Parpola to 670-IV/V

As for myself, I am presently [col]lecting all the thirty to forty canonical tablets that are relevant to the matter, as well as (all) the existing non-canonical ones that are ever [per] formed (in this connection).

$S A A \times 245$ r. $12-18(=A B L 453)$

(f) Letter of Marduk-šākin-šumi, dated by Parpola to 670-IX-22

Concerning the ritual about which the king said yesterday: "Get it done by the 24th day" - we cannot make it; the tablets are too numerous, (god only knows) when they will be written ... And concerning the Sumerian texts of the counterspells about which the king said: "Send (word)! They should be brought from Nineveh!" - I shall send Nādin-ahhēe; he will go and bring them. He will also bring with them the other tablets of the "refrain series". Let the king perform (his part) on the 2 nd of Tebet (X), the crown prince on the 4 th and the people on the 6 th.

$S A A \times 255: 5-10$ and r. $1-13(=A B L 18)$

(g) Letter of Adad-šum-uṣur and Marduk-šākin-šumi, dated by Parpola to the end of IX-670

Concerning what the king wrote to us, [he has a] ssigned it as follows: "Once he is through with the [Sum]erian counterspells, he should thereafter finish the antiphone (series). Thereafter the others should do likewise."

SAA X 256: 6-r. $7(=A B L 11)$

The first letter (passage a) seems clearly to refer to a programme of copying tablets in large numbers for Ashurbanipal's palace. Alongside passage (a) should be mentioned a more fragmentary letter that gives details of individual scribes at work preparing individual texts, some of them in multiple copies (SAA X 102). Passage (b) documents the copying of tablets under duress by men who appear to be high-born Babylonian prisoners, including Ninurta-gimilli, the son of the governor of Nippur (see Parpola 1972: 33). Letter (c) attests a process of identifying tablets worth keeping for posterity. Neither (b) nor (c) certainly dates to the reign of Ashurbanipal.

Although we usually associate the collecting of scholarly tablets with Ashurbanipal, in view of his claims of great scholarly ability and achievement, some of the Kuyunjik letters on this topic appear to come from the reign of his father and predecessor, Esarhaddon. The last four letters quoted above $(\mathrm{d}-\mathrm{g})$ have been so dated by Parpola and show that scholarly tablets were already then copied for use in connection with the king and his family. While Esarhaddon did not make the expansive claims to personal scholarship that his son did, he does mention in passing that he could write (Borger 1956: 6 Ass. A vii 39 al-tu-ur), and evidently had a keen interest in scholarship. It is not clear whether the tablets at issue in passages ( $-\mathrm{g})$ were to go into a royal collection or into the personal collections of the scholars advising and assisting the king. In any case, this may be a modern distinction that would not obtain in seventh-century Assyria. The Kuyunjik collections are heterogeneous regarding the nature and age of the tablets they contain. The royal libraries of Nineveh held private archival documents as well as library tablets, and among both are certainly many tablets that were written before Ashurbanipal was born, some of Middle Assyrian date and many early Neo-Assyrian, e.g. eighth century (on the mixed age of the K tablets see George 2003: 381-91). A process of acquiring tablets was evidently already under way long before Ashurbanipal's accession in 668. This may have been a matter of accumulation by default, or it may have been a more active policy by royal command. A programme of copying scholarly tablets might very well have been part of such an initiative. If so, Ashurbanipal's tablet-copying activities represent a continuation of his predecessors' policy, but on a larger and more ambitious scale.

Ashurbanipal's own inscriptions. As is well known, in some of his inscriptions Ashurbanipal claimed to have been well educated and to have possessed advanced knowledge of scholarly matters (see e.g. Villard 1997). Relevant passages from his royal inscriptions are the following two excerpts:

The god Nabû, the scribe of all things, granted me the precepts of his craft as a gift ... I learned the craft of the sage Adapa, the secret lore of all scribal learning. I am knowledgeable about celestial and terrestrial portents (and) can discuss (them) in the assembly of scholars. I am able to argue with expert diviners about the series "If the liver is a correspondence of the sky". I can solve complicated divisions and multiplications which do not have a solution. I have read cunningly written text(s) in obscure 
Sumerian (and) Akkadian that are difficult to unravel. I have examined confused kakku sakku inscriptions on stone (dating) from before the Flood.

Asb. $\mathrm{L}^{4}$ i $11-18$

Moreover, I, Ashurbanipal, acquired there the craft of Nabû, all scribal learning. I have studied the lore of every single one of the master scholars.

Asb. A i 31-3

Many examples of Ashurbanipal's various colophons survive on scholarly tablets found at Nineveh (Hunger 1968: Nos. 317-45). Several different colophons refer to Ashurbanipal's own knowledge of scribal lore, while others report the copying of tablets from Sumer, Akkad and Babylon, and thus bear witness to a large-scale copying programme at Nineveh during his reign. Excerpts from four colophons will suffice:

Ashurbanipal, great king, mighty king, king of the world, king of Assyria ... I have written, checked and collated this tablet among the assembly of scholars according to the wording on tablets (and) writing-boards, exemplars from Assyria, Sumer and Akkad; I have placed (it) inside my palace for my royal inspection.

Hunger 1968: No. 318, 1-8

Tablet of Ashurbanipal ... who has learned and ruminated on the art of the diviner, the knowledge pertaining to the secrets of the sky and earth, the wisdom of the gods Šamaš and Adad.

Hunger 1968: No. 325, 1-3

For the god Nabû, ... who grasps the writing-board (and) holds the reed (stylus) for (writing on) the Tablet of Destinies ..., his lord: I, Ashurbanipal ... wrote on tablets the wisdom of the god Ea, the lore of the lamentation-priest, the secret knowledge of the sages which is suited for soothing the hearts of the great gods, according to the wording on tablets, exemplars from Assyria and Akkad. I checked, collated and deposited (them) in the library ( girginakku) of Ezida, the temple of the god Nabû, my lord, in Nineveh.

Hunger 1968: No. 328, 1-18

Written and collated according to the wording on a writing-board, an exemplar from Babylon.

Hunger 1968: No. 331, 1; Borger 1969-70: 168

There is undoubtedly a great deal of hyperbole here and we cannot blindly assume that Ashurbanipal copied any or all of the tablets bearing colophons stating that he did. Nevertheless, the above passages demonstrate that Ashurbanipal was personally interested in and involved with the copying and collection of scholarly tablets from Babylonia and Assyria for use by himself and at his court. For the most part, the fields of scholarship in which this Assyrian king claimed expertise are those documented by letters as collected and/or copied, those listed prominently in the Assyrian library records, and those attested frequently at Nineveh in the tablet collections bearing colophons of Ashurbanipal. All support the conclusion that Ashurbanipal was very actively behind the collection of scholarly texts from Babylonia and Assyria for the royal libraries at Nineveh, and that the collection of texts was complemented by a major programme of tabletcopying. While the sources clearly indicate that tablet-copying went on in Nineveh, some copying of tablets was done elsewhere, for example in the city of Assur (Villard 1998). The new texts demonstrate that the copying programme took place in Babylonian centres too.

Later scribal tradition. Hitherto the principal non-contemporaneous evidence for Ashurbanipal's tablet collecting has been the much cited Neo-Babylonian letter inscribed on two Late Babylonian scribal exercise tablets from Borsippa. The tablets (BM 25676 $=98-2-16,730$ and BM $25678=$ 98-2-16, 732) were acquired by the British Museum from Selim Homsy and Co. The text they hand down, whether a genuine document or not, preserves the memory of a king's forced requisition of tablets from private libraries and the temple E-zida in Borsippa, including a "shopping list" of texts that were particularly desirable. In the absence of a modern English translation, it is worth quoting in full:

a-mat šarri(lugal) $a-n a{ }_{\breve{s} a ́-d u-n u}{ }^{2} \check{s} u l-m u$ ia-a-ši lib-ba-ka lu-u ta-ab-ka ${ }^{3} u_{4}-m i$ tup-pi ta-mu-ru ${ }^{\mathrm{m}_{\breve{s} u-m a-}}$

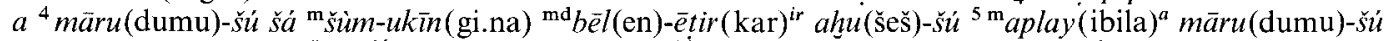

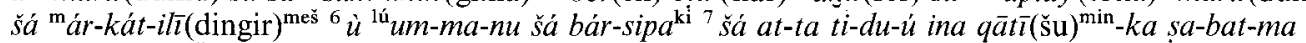

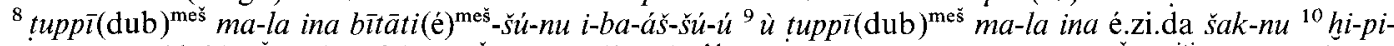

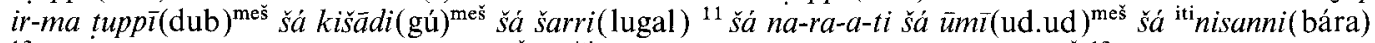

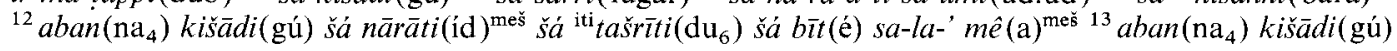




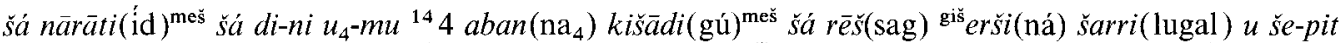

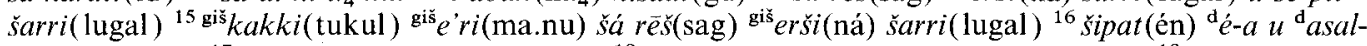
lú-ȟe né-me-qa ${ }^{17}$ li-gam-me-ru-ni pu-uh-huu-ru ${ }^{18}$ iškar (éš.gàr) tāhăazi(mè) ma-la ba-šúu-ú ${ }^{19} a$-di

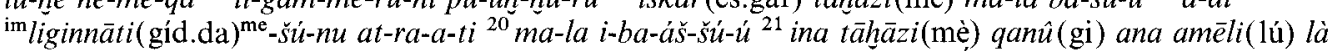
tehêe(te) ${ }^{e}{ }^{22}$ eden.na.dib.bé.da é.gal. $\mathrm{ku}_{4} \cdot \mathrm{ra}^{23}$ né-pe-šá-a-nu šu'illakāni(šu.íl.la.kam) ${ }^{a-n u}{ }^{24}$ mál-ta-ru šá

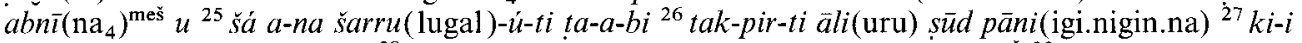
na-qut-ti u mim-ma hi-ših-ti ${ }^{28}$ ina ekalli(é.gal ) ma-la ba-šú-ú ù tuppī(dub $)^{\text {meš } 29} a q-r u-t u$ śa mé-dak-kunu-šim-ma ${ }^{30}$ ina māt (kur) aš-šur ${ }^{\mathrm{ki}}$ ia-'-nu bu-'-a-nim-ma ${ }^{31}$ šu-bi-la-a-ni a-du-u a-na ${ }^{32}$ lúšatammi (šà.tam)

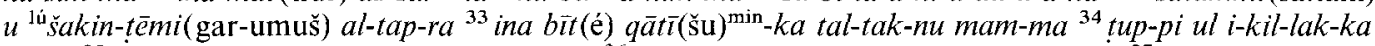
$u$ ki-i ${ }^{35}$ mim-ma tup-pi u né-pe-š́̉ šá a-na-ku ${ }^{36}$ la áš-pu-rak-ku-nu-š́ u ta-tam-ra-ma ${ }^{37} a-n a$ ekalli(é.gal )-ia ta-a-bu ${ }^{38}$ it-ti-'-im-ma i-šá-nim-ma ${ }^{39}{ }^{3}$ ś-bi-la-a-ni

CT 221 (Ebeling 1949: No. 1, Lieberman 1990: 334-6)

The command of the king to Šadûnu: ${ }^{2} \mathrm{I}$ am well, you should be happy. ${ }^{3}$ The day you read this tablet, take in your company Šumāy ${ }^{4}$ son of Šum-ukīn, his brother Bēl-ētir, ${ }^{5}$ Aplāy son of Arkât-ilī, ${ }^{6}$ and the scholars of Borsippa ${ }^{7}$ whom you know, and ${ }^{10}$ collect ${ }^{8}$ whatever tablets are in their houses ${ }^{9}$ and whatever tablets are kept in E-zida. ${ }^{30}$ Search out for me:

${ }^{10}$ amulet-tablets for the king, ${ }^{11}$ for (crossing?) rivers, (tablets) to do with days (i.e., hemerologies), (menologies/rituals) of Nisannu, ${ }^{12}$ stone amulets for (crossing?) rivers, (menologies/rituals) of Tašritu, (tablets) of (the ritual) House of Water-Sprinkling, ${ }^{13}$ \{stone amulets for (crossing?) rivers \}, for (success in?) lawsuits, "Day", ${ }^{14}$ sets of four stone amulets for the head of the king's bed and the foot of the king's (bed), ${ }^{15}$ (the ritual) Wand of E'ru-Wood, for the head of the king's bed, ${ }^{16}$ the incantation "Let Ea and Asalluhe use wisdom ${ }^{17}$ in full for me!", (tablets of) "Mustering" (the army?), ${ }^{18}$ series to do with war, as many as there are, ${ }^{19}$ including their additional tablets, ${ }^{20}$ as many as there are,

${ }^{21}$ (the ritual) So that in Battle Arrows do not Come Near a Man, ${ }^{22}$ (the series) Travelling through the Country, (the series) Entering the Palace, ${ }^{23}$ (medical?) rituals, šuilla-prayers, ${ }^{24}$ inscriptions on stone amulets and ${ }^{25}$ those that are good for kingship, ${ }^{26}$ (the ritual) Purification of the City, (spells against) Dizziness, ${ }^{27}$ (the medical text?) "Out of Concern"

and any texts that might be needed ${ }^{28}$ in the palace, as many as there are, also rare ${ }^{29}$ tablets that are known to you but ${ }^{30}$ do not exist in Assyria, and ${ }^{31}$ send them to me.

Now, ${ }^{32}$ I have written to the temple-steward and the governor: ${ }^{33}$ in the houses where you set to work nobody ${ }^{34}$ will withhold tablets from you (sg.). And if, ${ }^{35}$ furthermore, you (pl.) come across any tablet or ritual which I myself ${ }^{36}$ have not mentioned to you (pl.) and ${ }^{37}$ it is beneficial to my governance, ${ }^{38}$ take it too and ${ }^{39}$ send it to me. ${ }^{4}$

Lieberman thought this letter improbable evidence for Ashurbanipal's activities, attributing it to an Assyrian king other than Ashurbanipal or to Babylonian fantasy (Lieberman 1990: 312). In general he supposed that Ashurbanipal would have no need of these texts to help him govern, being the scion of a long line of experienced kings, and there were such tablets in Assyria anyway. In this he took no account of perhaps a collector's obsessive desire to possess everything. While he noted the heavy reliance of some Sargonid kings on written tradition as a source of advice for good government, and discussed fully Ashurbanipal's desire personally to master and control the interpretation of that tradition, he failed to see that royal interest in the sources of professional lore would have encouraged the collection of multiple exemplars of scholarly texts from all over the empire. In addition Lieberman observed that no tablets found in Ashurbanipal's library claim to be copies made from exemplars from Borsippa. That may be so but he ignored the fact that several tablets formerly in the property of E-zida at Borsippa, as stated in their colophons, actually survived to be excavated in the remnants of Ashurbanipal's library and so confirm this city as the place of origin of some of the library's tablets. These include copies of a list of stars, of Enuma eliš IV, and of a ki. ${ }^{\mathrm{d} u t u}$.kam incantation (Hunger 1968: Nos. 135-6, 140a).

The texts that the king demands Šadûnu send him do not, however, exhibit the full range of scholarly and professional expertise that informed Sargonid government. They are texts of ăsipūtu "exorcists' lore", especially prophylactic and apotropaic magic. Divinatory compositions are notably absent. The overwhelming impression given by the letter is that the royal author wanted texts that would above all protect his person from sickness and keep him free of injury. In this there is a contrast with BM 45642 and 28862 , where the emphasis is on everything - the whole

\footnotetext{
${ }^{4}$ As pointed out by Streck 1995: 163, a literal translation yields: "And furthermore, any tablet or ritual, which I myself have not mentioned to you but you come across, if it is beneficial to my governance, take it too and send it to
}

me." This makes for clumsy English as well as inelegant Akkadian, and we have emended the wording slightly to what the sender of the letter surely wanted to say. 
corpus of scribal learning - and the only text mentioned specifically (beyond the summary list of the great text corpora in BM 28825: 8-9) is an academic aid. Given the predisposition of Esarhaddon, Ashurbanipal's father, to illness, and the evidence of the many letters from his advisers that his health was a preoccupation at court, it may yet be that he, not his son, was the author of the letter to Šadûnu.

Whether or not the letter to Šadûnu was written for Esarhaddon or for Ashurbanipal, BM 45642 and 28825 prove beyond doubt that Ashurbanipal did indeed order the collecting and copying of scholarly tablets in Babylonia. He wanted tablets from Borsippa and Babylon and the local scholars were keen to oblige him. No doubt he got them. The new texts reveal that the rewards promised to those who discharged the royal commission were immense. In their much briefer quotation of the royal instruction the scholars of Borsippa do not cite any promise of payment by the king; they are keen simply to assure the king that the job is in hand. The companion piece gives more detail. At Babylon Ashurbanipal offered financial inducements and political concessions so generous that, when the news spread around the city, a huge crowd gathered amid great excitement. The sums of money that the scholar-king of Assyria was willing to spend on completing his library show just how important it was to him.

The question of date arises. The process began long before the mass requisitions documented by the library records dated to 647 . Since BM 28825 mentions the involvement of Šamaš-šumukin in his brother's affairs, the new texts show that the Assyrian king was already collecting large quantities of texts from Babylonia early in his reign, not by force but by a programme of copying in the great temple libraries of Babylon and Borsippa. The period in question was clearly before the outbreak of rebellion in 652, when relations with Šamaš-šum-ukin broke down. If the date inserted in BM 28825 accurately reports the year of Ashurbanipal's engagement of the scholars of Babylon, the programme of copying began in 664. The commission quoted in BM 45642, which refers to copying tablets at Borsippa, could in theory date to either before or after the rebellion but, given its detailed similarity in wording to the companion text from Babylon, it very probably records the Borsippans' response to the same royal commission, and thus also dates to 664 .

Both BM 45642 and BM 28825 refer to writing texts on waxed writing-boards of a valuable hardwood known as musukkannu. This wood, now identified as sissoo, ${ }^{5}$ was eminently suitable as material for writing-boards intended for the Assyrian king. Writing-boards, Akk. le' $u$ and daltu, were used for both royal library collections and administrative purposes in the first millennium. ${ }^{6}$ It is already known from the Assyrian library records that hundreds of texts inscribed on such boards were collected from private libraries, many of them in Babylonia (Parpola 1983: 4). BM 45642 reveals that when the Borsippan scholars responded to the king's demand for texts, they did so by sending him writing-boards rather than clay tablets, perhaps because boards were more precious and thus more fitting for a king, or perhaps because they were easier to transport. Writing-boards normally perish from the archaeological record, so it is not possible to tell whether all the boards sent to the king in response to his commission became part of the royal holdings, nor whether those taken by him after the revolt joined them.

Given that there was a very productive copying programme going on at Nineveh in Ashurbanipal's time, it may be that many writing-boards were used as master exemplars and for collation in the making of exemplars on clay, and then returned whence they came. This may

\footnotetext{
${ }^{5}$ For the identification of musukkannu with Dalbergia sissoo, see most recently Maxwell-Hyslop 1983 and Postgate 1992: 183. Another board made of this wood occurs in a small fragment from Nineveh, $C T 51222: 1^{\prime}$ gis $\left.l e\right]^{-\top} u_{5}{ }^{\top}-u m$ gišmes.má.gan.na (part of a colophon?). Writing-boards made of walnut and ivory were found at Nimrud (Mallowan 1954: 98) and there are references in Assyrian texts to boards of tamarisk (bīnu) and cypress (šurmēnu) (see CAD L 159 sub $l \bar{e}^{\prime} u$ b. $3^{\prime} \cdot \mathrm{b}^{\prime}$ and Weidner 1941-4: 177). The Late Bronze Age board found in the shipwreck of Ulu Burun was of boxwood (Warnock and Pendleton 1991).

"The term daltu, literally "door-leaf", means a single board that did not belong to a polyptych (Stol 1998). For the manufacture and use of writing-boards see Nemet-Nejat
}

2000. Sixteen ivory writing-boards that may have all come from the same polyptych were found by Mallowan in a well of the North-West Palace at Nimrud. The outer surface of one writing-board (ND 3557) bore an inscription stating that it belonged to Sargon II and contained the astronomical omen series Enūma Anu Ellil (cf. BM 28825: 23); see Mallowan 1954: 98-9 and Pl. 23; Wiseman 1955. For a technical description of these boards see Howard 1955. An ivory writing-board was also found at Assur (KlengelBrandt 1975). For the use of writing-boards in the temple administration at Sippar in the Neo-Babylonian and Achaemenid periods, see MacGinnis 2002. For such boards in the second millennium see Symington 1991 and Postgate 1986: $22-6$. 
have been common practice for tablets too. The Assyrian library records show that clay tablets were imported from Assyrian and Babylonian private libraries in their thousands. The remains of the excavated library, however, include comparatively few tablets in Babylonian script (Fincke 2004), and only a small proportion of tablets are identified by colophon as originating in private possession. Parpola pointed out that the tablets and boards listed in the Assyrian library records were taken while their owners still lived, rather than after their deaths (Parpola 1983: 9). It is conceivable that many were not so much confiscated as requisitioned temporarily for copying and then returned to their owners. The same may have been true of the tablets collected for the king in response to his letter to Šadûnu. In this regard it is suggestive that the two texts published here envisage the transfer to Assyria not of original tablets but of copies made locally for the purpose.

Like both copies of $C T 221$ known to us, BM 28825 and BM 45642 are late copies. Long after the fall of Assyria, these three documents continued to be read, learned and copied by Babylonian scribes. As such they are further evidence for a long-standing practice, the adoption of royal correspondence into the scribal tradition as pedagogical tools. The Sumerian royal correspondence of the Old Babylonian curriculum is well known as a literary genre, but their Akkadian counterparts in the first-millennium curriculum are less often thought of in such terms. Some of these Akkadian royal letters are clearly bogus, either because they are self-evidently ahistorical fantasies, like the Letter of Gilgameš, or because they are royal or religious propaganda, like the much-copied letters of Sargon of Akkade, of a king of Isin whose name is lost (a text formerly known as the Weidner Chronicle), of Samsuiluna and of Kurigalzu of Babylonia (see George 2003: 117-18).

The three letters that report the commissioning of the copying and collection of Babylonian scholarly texts for the Assyrian king (or kings) are not obviously driven by ideological or other tendentious motives. As historical documents they fit the picture of Ashurbanipal's tablet collecting and scholarly interests already gained from the seventh-century sources cited above. In particular, the five specific categories of text requested by Ashurbanipal in BM 28825: 9 are almost all mentioned in the library records. The single exception, the song corpus (narutu), may, as noted earlier, be a scribal error for haruspical omens ( $b \bar{a} r \hat{t} t u)$, which occur frequently in the records and are very well represented in the extant Kuyunjik collections. Accordingly we suppose that the three letters are copies of genuine documents.

The reason for the inclusion of these texts in the scribal curriculum was surely a matter of intellectual prestige. When Ashurbanipal was collecting the greatest library the world had ever known, he turned for help to the learned and expert scholars of Babylon and Borsippa. Accordingly the texts inscribed on the tablets published here must have held a special place in the collective memory of the intellectual élites of these cities. Still passed down after perhaps half a millennium, they were proud reminders of the local scholars' finest hour.

\section{References}

Annus, Amar 2002. The God Ninurta in the Mythology and Royal Ideology of Ancient Mesopotamia. SAA Studies 14 (Helsinki).

Borger, R. 1956. Die Inschriften Asarhaddons, Königs von Assyrien. Archiv für Orientforschung, Beiheft 9 (Graz).

Borger, R. 1969-70. Bemerkungen zu den akkadischen Kolophonen. Welt des Orients 5: 165-71.

Brinkman, J. A., and D. A. Kennedy 1986. Documentary evidence for the economic base of early NeoBabylonian society: A survey of dated Babylonian economic texts, 721-626 в.c. Journal of Cuneiform Studies 35: 1-90.

Dijk, J. van 1989. Ein spätaltbabylonischer Katalog einer Sammlung sumerischer Briefe. Orientalia 58: 441-52. Ebeling, Erich 1949. Neubabylonische Briefe. ABAW NF 30 (Munich).

Fincke, Jeanette 2004. The British Museum's Ashurbanipal library project. Iraq 66: 55-60, republished in Dominique Collon and Andrew George (eds.), Nineveh. Papers of the XLIXe Rencontre Assyriologique Internationale, London 7-11 July 2003 (London, 2005).

Frahm, Eckart in press. Headhunter, Bücherdiebe und wandernde Gelehrte: Anmerkungen zum altorientalischen Wissenstransfer im ersten Jahrtausend v. Chr. Colloquien, Deutsche Orient-Gesellschaft 4.

George, A. R. 1986. Sennacherib and the Tablet of Destinies. Iraq 48: 133-46.

George, A. R. 1997. Assyria and the western world. In S. Parpola and R. M. Whiting (eds.), Assyria 1995. Proceedings of the 10th Anniversary Symposium of the Neo-Assyrian Text Corpus Project, Helsinki, September 7-11, 1995 (Helsinki): 69-75. 
George, A. R. 2003. The Babylonian Gilgamesh Epic. Introduction, Critical Edition and Cuneiform Texts. 2 vols. (Oxford).

Howard, M. 1955. Technical description of the ivory writing-boards from Nimrud. Iraq 17: 14-20.

Hunger, Hermann 1968. Babylonische und assyrische Kolophone. AOAT 2 (Kevelaer and Neukirchen-Vluyn).

Klengel-Brandt, E. 1975. Eine Schreibtafel aus Assur. Altorientalische Forschungen 3: 169-71, Pls. $21-2$.

Lambert, W. G. 1957. Ancestors, authors and canonicity. Journal of Cuneiform Studies 11: 1-14, 112.

Lambert, W. G. 1976. A Late Assyrian catalogue of literary and scholarly texts. In Barry L. Eichler (ed.), Kramer Anniversary Volume. Cuneiform Studies in Honor of Samuel Noah Kramer. AOAT 25 (Kevelaer and Neukirchen-Vluyn): 313-18.

Lambert, W. G. 1989. The laws of Hammurabi in the first millennium. In M. Lebeau and P. Talon (eds.), Reflets des deux fleuves: Volume de mélanges offerts à André Finet (Leuven): 95-8.

Lambert, W. G. 1992. Addenda et corrigenda to W. G. Lambert, Catalogue of the Cuneiform Tablets of the Kouyunjik Collection of the British Museum, Third Supplement (1992). Nouvelles assyriologiques brèves et utilitaires 1992, 4: 95-6 No. 129.

Lieberman, Stephen J. 1990. Canonical and official cuneiform texts: Towards an understanding of Assurbanipal's personal tablet collection. In Tzvi Abusch, John Huehnergard and Piotr Steinkeller (eds.), Lingering over Words. Studies in Ancient Near Eastern Literature in Honor of William $L$. Moran (Atlanta): 305-36.

MacGinnis, J. 2002. The use of writing boards in the Neo-Babylonian temple administration at Sippar. Iraq 64: $217-36$.

Mallowan, M. E. L. 1954. The excavations at Nimrud (Kalhu), 1953. Iraq 16: 59-16, Pls. 10-36.

Maxwell-Hyslop, K. R. 1983. Dalbergia Sissoo Roxburgh. Anatolian Studies 33: 67-72.

Mayer, Werner R. 1992. Ein Hymnus auf Ninurta als Helfer in der Not. Orientalia 61: 17-57.

Nemet-Nejat, K. R. 2000. An administrative text about writing boards (557 B.C.E.). Baghdader Mitteilungen 31: $249-58$.

Neugebauer, O. 1955. Astronomical Cuneiform Tablets 1 (London).

Parpola, Simo 1972. A letter of Šamaš-šumu-ukīn to Esarhaddon. Iraq 34: 21-34.

Parpola, Simo 1983. Assyrian library records. Journal of Near Eastern Studies 42: 1-29.

Postgate, J. N. 1986. Middle Assyrian tablets: The instruments of bureaucracy. Altorientalische Forschungen 13: $10-39$.

Postgate, J. N. 1992. Trees and timber in the Assyrian texts. Bulletin on Sumerian Agriculture 6: 177-92.

Reade, J. E. 1986. Introduction. In Erle Leichty, Catalogue of the Babylonian Tablets in the British Museum VI. Tablets from Sippar 1 (London): xiii-xxxvi.

Schaudig, Hanspeter 2001. Die Inschriften Nabonids von Babylon und Kyros' des Grossen samt den in ihrem Umfeld entstandenen Tendenzschriften. Textausgabe und Grammatik. AOAT 256 (Münster).

Stol, Marten 1998. Einige kurze Wortstudien. In S. M. Maul (ed.), Festschrift für Rykle Borger zu seinem 65. Geburtstag am 24. Mai 1994: Tikip santakki mala bašmu ... Cuneiform Monographs 10 (Groningen): 343-52.

Streck, Michael P. 1995. Zahl und Zeit. Grammatik der Numeralia und des Verbalsystems im Spätbabylonischen. Cuneiform Monographs 5 (Groningen).

Symington, Dorit 1991. Late Bronze Age writing-boards and their uses: Textual evidence from Anatolia and Syria. Anatolian Studies 41: 111-23.

Tallqvist, Knut 1938. Akkadische Götterepitheta. Studia Orientalia 7 (Helsinki).

Villard, P. 1997. L'éducation d'Assurbanipal. Ktèma 22: 135-49.

Villard, P. 1998. Kiṣir-Aššur et la bibliothèque de Ninive. Nouvelles assyriologiques brèves et utilitaires 1998 , 1: 19 No. 16.

Warnock, Peter, and Michael Pendleton 1991. The wood of the Ulu Burun diptych. Anatolian Studies 41: $107-10$.

Weidner, E. F. 1941-4. Die astrologische Serie Enûma Anu Enlil. Archiv für Orientforschung 14: 172-95.

Wiseman, D. J. 1955. Assyrian writing-boards. Iraq 16: 3-13, Pls. 1-3.

Woodington, N. R. 1982. A Grammar of the Neo-Babylonian Letters of the Kuyunjik Collection (Doctoral dissertation, Yale University).

Wunsch, Cornelia 2000. Das Egibi-Archiv. 2 vols. Cuneiform Monographs 20A-B (Groningen).

Wunsch, Cornelia 2003. Urkunden zum Ehe-, Vermögens- und Erbrecht aus verschiedenen neubabylonischen Archiven. Babylonische Archive 2 (Dresden). 